\title{
"Ugrilaista alkuvoimaa"
}

\section{Värttinä, Äijö ja suomalais-ugrilaisen perinteen uudelleentulkinta}

Suomalainen maailmanmusiikki on parhaillaan kovassa kurssissa maailmalla. Toisin kuin esimerkiksi kansainvälisesti menestyneen suomalaisen rockin (HIM), teknon (Darude) tai rapin (Bomfunk MC's) kohdalla, tässä ilmiössä on kysymys nimenomaan suomalaisen tai suomalais-ugrilaisen perinteen välittämisestä - tai pikemmin uudelleentulkinnasta - sekä suomalaiselle että kansainväliselle yleisölle. Tarkastelen seuraavassa tätä uudelleentulkintaprosessia Värttinän Äijö-biisin (1999) kautta. ${ }^{1}$ Kiinnitän huomiota siihen, millä tavoin yhtye muokkaa ja uudelleentulkitsee suomalaisugrilaista perinnettä Äijössä, miten tätä "ugrilaista alkuvoimaa" ja sen uudelleentulkintaa hyödynnetään markkinoinnin yhteydessä sekä millaisia merkityksiä suomalainen ja kansainvälinen vastaanottajakunta lopputulokselle antaa. ${ }^{2}$ Käytän analyysissa julkisesti saatavilla olevia aineistoja, jotka edustavat välittymisprosessin eri vaiheita: tuotantoa (biisinteko- ja äänitysprosessia koskevat kuvaukset), markkinointia (levyja konserttitiedotteet), julkista vastaanottoa (reportaasit, haastattelut, kritiikit) ja faniyleisön kommentteja (Värttinän kotisivujen keskustelupalstalla esitetyt ajatukset). Täydennän tätä aineistoa säveltäjä Antto Varilon, sanoittaja Kirsi Kähkösen ja äänittäjä Risto Hemmin haastatteluilla.

\section{Näkökulmia nykykansanmusiikin tutkimukseen}

Värttinän musiikkia on luonnehdittu maailmanmusiikiksi, uudeksi kansanmusiikiksi ja nykykansanmusiikiksi. Käsitän nämä termit tässä toistensa synonyymeiksi. Nykykansanmusiikki sisältää aineksia sekä perinne- että populaarimusiikista ja sen esillepano toimii populaarimusiikin tavoin musiikkiteollisuuden ja mediakulttuurin ehdoilla (Kurkela 1995; Pekkilä 1998). Pekkilän mukaan nykykansanmusiikkia tulisikin tar- 
kastella sekä kansanmusiikin että populaarimusiikin näkökulmasta. Tämä tehtävä näyttää kuitenkin sikäli ristiriitaiselta, että niin kansanmusiikkia kuin populaarimusiikkiakin on määritelty juuri näiden musiikinlajien toisistaan poikkeavien välittymistapojen mukaan.

IFMC (International Folk Music Council) määritteli kansanmusiikin São Paulon konferenssissa vuonna 1954 välittymistavan perusteella seuraavasti:

Kansanmusiikki on sellaisen musiikillisen tradition tuote, joka on kehittynyt suullisen välittymisprosessin kautta. Ne tekijät, jotka muovaavat traditiota ovat (i) jatkuvuus, joka yhdistää nykyhetken menneeseen; (ii) muuntelu, joka syntyy yksilön tai ryhmän luovasta impulssista; ja (iii) yhteisön valinta, joka määrää sen muodon tai ne muodot, joissa musiikki säilyy.

(Ling, Lönn \& Ala-Könni 1978: 346; ks. myös Karpeles 1973: 3.)

Määrittelyssä kerrotaan edelleen, että kansanmusiikkia on musiikki, "johon populaari- tai taidemusiikki ei ole vaikuttanut", ja että termi "ei peitä sävellettyä populaarimusiikkia, jonka yhteisö on omaksunut valmiina ja säilyttänyt sellaisenaan" (Ling, Lönn \& Ala-Könni 1978: 346). IFMC:n määritelmä on lähes 50 vuotta vanha kulttuuripoliittinen julkilausuma, joka on muotoiltu myös kansanmusiikin tutkimusta laajempia käyttöyhteyksiä silmällä pitäen. Silti se on edelleenkin ajankohtainen lähtökohta spesifimmille kansanmusiikin määrittely-yrityksille (vrt. Pegg 2003).

Populaarimusiikkia määrittelevänä tekijänä on taas pidetty sitä, että se välittyy musiikkiteollisuuden ja median ehdoilla. Tämän näkökulman mukaisesti tutkimuksessa on kiinnitetty huomiota erityisesti seuraaviin aspekteihin:

- musiikin tuottaminen (säveltäminen, sanoittaminen, sovittaminen, esittäminen, äänittäminen, miksaaminen);

- markkinointi (levytiedotteet, mainokset, promolevyt ja -videot);

- musiikkijournalismi (uutisointi, reportaasit, konsertti- ja levyarvostelut, kolumnit);

- musiikin kuluttaminen (levyjen ja radion kuuntelu, TV:n ja musiikkivideoiden katselu, konserteissa käynti).

Kaikkia näitä aspekteja käsittelee esimerkiksi Simon Frith klassikoksi muodostuneessa kirjassaan Sound Effects (1987). Frithin teoksen vanavedessä ilmestyi myös Suomessa muutama edellä mainittuja aspekteja eri näkökulmista käsitellyt kirja (Lassila 1987; Muikku 1988; Oesch 1989; Lähteenmaa 1989; Lehtiranta \& Saalonen 1993). Myös akateeminen Värttinä-tutkimus on noudatellut vastaavia linjauksia. Mukaan mahtuu tilastollista yleisötutkimusta (van Elderen 1993, 1994 ja 1996), diskurssianalyyttista journalistiikkaa (Pensas 1995), teemahaastatteluun perustuvaa reseptiotutkimusta (Offermann 1998) sekä oman toiminnan subjektiivista erittelyä (Kaasinen 1994). Edellisten lisäksi on vielä mainittava tutkivan journalismin näkökulma, jota edustaa Kimmo Nevalaisen virallinen Värttinä-biografia Korkeelta ja kovvoo - histo- 
ria, musiikki ja nuotit (2001). Populaarimusiikin tutkimuksen lähestymistapojen soveltamiselle on siis Värttinä-tutkimuksessakin jo pitkä perinne. Lähdenkin seuraavassa siitä, että Värttinän musiikkia on mielekästä tarkastella nimenomaan yhdistämällä kansanmusiikin ja populaarimusiikin tutkimuksen näkökulmat.

\section{Tutkimuksen suorittaminen}

Valitsin Äijön tapausanalyysin kohteeksi ennen muuta siksi, että kappaleesta on julkaistu paitsi studio- ja live-äänite myös video. Kansanmusiikki- ja populaarimusiikkinäkökulmien mukaisesti päädyin selvittämään

- millä tavoin Värttinä Äijön kohdalla jatkaa ja muuntelee suomalais-ugrilaista perinnettä ja millä tavoin tämä tulee esiin yhteisön palautteessa (kritiikeissä, fanien kommenteissa), sekä

- millä tavoin musiikkiteollisuuden ja median toimintamekanismit tulevat esiin $\ddot{A} i$ jön tuotannon, markkinoinnin ja vastaanoton ("kulutuksen") kohdalla?

Menetelmänä on sekä julkisesti saatavilla olevan aineiston että nimenomaan tätä tutkimusta varten haastattelemalla keräämäni aineiston analyysi ja tulkinta. Julkisesti saatavilla oleva aineisto rakentuu seuraavasti:

- Ilmatar-ja 6.12.-albumit

- Kimmo Nevalaisen Värttinä-biografia

- levy-yhtiöiden (BMG Finland, NorthSide) ja jälleenmyyjien (Amazon.com, Barnes \& Noble) tiedotteet, Värttinän viralliset kotisivut

- kritiikit, reportaasit ja haastattelut sanoma-, aikakaus- ja verkkolehdissä

- fanien keskustelupalsta (Forum) Värttinän virallisilla sivuilla

Lisäksi haastattelin $\ddot{A} i j o ̈ n$ säveltäjää Antto Variloa ja sanoittaja Kirsi Kähköstä sekä Ilmatar-albumin äänittäjää Risto Hemmiä. Kähkösen ja Hemmin haastattelun tein puhelimitse, Varilolle lähetin sähköpostitse avoimia kysymyksiä sisältävän listan, johon hän vastasi niin ikään sähköpostitse.

Aineiston kuvauksen, luokittelun, yhdistelyn ja tulkinnan yhteydessä sovelsin sekä fakta- että merkitysnäkökulmaa. Faktanäkökulmaa sovellettaessa tutkimuksen kohteena on tapahtumien kulku "virallisten" dokumenttien (äänitteet, tiedotteet jne.) ja niihin sisältyvien tietojen (päivämäärät, vuosiluvut, tekijätiedot jne.) valossa, kun taas merkitysnäkökulmaa sovellettaessa kohteena on paitsi tapahtumien kulku myös - ja ennen muuta - niiden merkitys prosessissa mukana olleiden subjektiivisten kokemusten valossa. Analyysi etenee kronologisesti ja jäsentyy populaarimusiikin välittymisen keskeisten vaiheiden mukaisesti. 


\section{Äijö: biisinteko-, treeni- ja studiovaihe}

Äijön taustalla on Antto Varilon Vihma-levyn aikoihin (1998) tekemä riffi, jonka hän ensin mieltää bassoriffiksi (Nevalainen 2001: 127). Inspiraationsa lähteistä Varilo (2002) kertoo seuraavaa:

En koe, että niissä olisi selviä vaikutteita. Usein kappaleeni (kuten Äijö) syntyvät voimakkaan tunnetilan aikana -ehkä jopa transsinomaisessa tilassa- jolloin en mielestäni ajattele tietoisesti. Lähtökohtana oli siis tunne, ei mikään aikaisemmin kuultu kappale. Uhka, yliluonnollinen tapahtuma, transsi, pelko ja keskiaika ovat sanoja, joilla voisin haaleasti kuvata silloista tunnetta tai visiota. En sävellä niin, että yrittäisin tehdä tietoisesti tietynlaista kappaletta, jolla olisi esikuva olemassa. Kari Reiman saattaisi ehkä säveltää niin...

Riffi jää lepäämään yli vuoden ajaksi, kunnes Värttinä alkaa syyskuussa 1999 treenata uuden albumin materiaalia. Tällöin Varilo kirjoittaa B-osan, jonka musiikillisia lähtökohtia hän kommentoi seuraavasti: 'B-osassa hain vastausta A-osalle. Jotain erilasista [sic], mutta täydentävää. Mielestäni oli hyvä idea soittaa se ylempää. (Sehän on erittäin käytetty tehokeino musiikissa...)" (Varilo 2002.) Kun A- ja B-osa ovat melodiansa puolesta valmiina, Varilo tuo biisin treeneihin. Tämä tapahtuu suunnilleen treenien keskivaiheilla (Varilo 2002). Kirsi Kähkösen (2002) mukaan "biisistä oli siinä vaiheessa vain Anton kitaralla tekemä melodia". Tekijä on tässä vaiheessa hieman epävarma muun bändin suhtautumisesta uuteen biisiin: "Se oli niin erilainen, (= urkupisteeseen ja pelkkään tunnetilaan perustuva "yksinkertainen" biisi) että sen esille tuominen ei ollut ihan helppoa tuossa musiikkinerojen yhtyeessä" (Varilo 2002). Biisi otetaan joka tapauksessa työn alle ja sanoituksen tekeminen annetaan Kirsi Kähkösen tehtäväksi.

Sanoitus lähtee syntymään, kun laulun teemaksi kiteytyy kylän äijä. Lähtökohtana on Varilon melodia ja suomen kielen sointi:

Teema löytyi siitä, että halusin käyttää siinä mahdollisimman paljon y-, ä- ja ö-kirjaimia. Värttinä keikkailee paljon ulkomailla ja nämä kirjaimet kuulostavat ulkomaalaisten korvissa erikoisilta tai jopa rumilta. Kylän äijä löytyi siitä, että siinä on y- ja äkirjaimia. Ja se yksinkertaisesti tuntui sopivan melodiaan.

(Kähkönen 2002; vrt. Nevalainen 2001: 127.)

Kylän äijä -teeman pohjalta syntyy kertosäkeistönä toimiva A-osa ja tämän ympärille tarinaa eteenpäin vievät B-osat. Kähkönen tuo sanoituksen treeneihin, jossa Riikka Timonen ehdottaa, että biisiin lisätään loitsuosuus. Kähkösen (2002) sanoin:

Joo, teksti oli muilta osin valmis. Riikka kuuli manauksen jollain kurssilla ja kun toin tekstin treeneihin, hän sanoi, että se manaus sopisi hyvin siihen. Hänellä oli se kurssilla jaettuna kopiona. 
Kähkönen ottaa loitsun työstettäväkseen. Kirjoitustyö etenee seuraavasti:

Se lähti siitä manauksesta liikkeelle ja lisäsin siihen sitten loppuosan omasta päästäni - - suunnilleen puoliväliin saakka se on siitä manauksesta - - et very miun verellä ja siitä eteenpäin ei tietenkään enää ole siitä, siihen saakka se on.

(Kähkönen 2002).

Loitsua seuraavat parannusmenot syntyvät vanhan suomalaisen sananlaskun "Jos ei viina, sauna ja terva auta, niin tauti on kuolemaksi” inspiroimana (Kähkönen 2002). Sanoituksessa puhutaan kylän äijästä, mutta biisin nimeksi tulee lopulta kuitenkin Äijö. Kähkönen (2002) itse muistaa biisin nimen kiteytymisen seuraavasti:

Minä sanoin, että nimi on Kylän äijä. Joku sanoi treeneissä, että se on Äijö. Muut olivat sitten samaa mieltä ja niin siitä tuli Äijö. Löytyyhän se Äijö niistä runoista. En nyt muista kuka sitä esitti ja oliko hän saanut sen jostakin.

Biisi sovitetaan alustavasti treeneissä. Kirsi Kähkösen (2002) mukaan kokonaismuodon eli rakenteen lähtökohtana on sanoitus: "Rakenne syntyi tekstin mukaan, eikä tekstiä muutettu treeneissä ollenkaan". Kun rakenne on alustavasti hahmotettu, vuorossa on soinnuttaminen. Varilo haluaa pitää biisin yksinkertaisena ja säilyttää urkupiste-idean, mutta bändi haluaa saada biisiin vaihtelua soinnutuksen avulla. Varilon (2002) omin sanoin:

Pyysin ystäviäni pysymään yhdessä urkupisteessä kerrallaan. Halusin pitää Äijön kappaleena, jossa ei olisi miljoona sointua. Janne Lappalainen on nero sointujen ja harmonioiden kanssa ja häneltä vain tuli samantien näin nerokkaita vaihtoehtoja. Pakkohan ne oli hyväksyä, ihania sointua!!! Onneksi urkupiste tunnelma [sic] kuitenkin pysyi --.

B-osien sointutaustoista Varilo (2002) kertoo: "Janne soinnutti spontaanisti muistaakseni yksissä harjoituksissa. Niin se tekee aina. Itse soinnutan yleensä kotona ja sata kertaa hitaammin." Säestävän laulustemman tekemisestä vastaavat Kari Reiman ja Mari Kaasinen (Kähkönen 2002). Intro ja välisoitot tehdään A-osan instrumenttisäestyksen pohjalta. A-osien ja välisoittojen instrumenttiosuudet transponoidaan kvinttiä korkeammalle B1- ja A2-osien väliin sijoittuvasta välisoitosta alkaen. Instrumentaatioon halutaan mukaan Lepistön soittama jouhikko, joka sisältyi jo Varilon alkuperäiseen ideaan etnosoitinten käytöstä biisissä, ja lisäväriä antamaan otetaan myös Varilon itsensä soittama cümbüs tanbur (turkkilainen pitkäkaulainen luuttu).

Lokakuussa tuottaja Hughes de Courson käy Helsingissä tapaamassa Värttinää:

Kävin ensin pikaisesti moikkaamassa bändiä Suomessa tutustuakseni heihin. Tämän jälkeen työskentelimme demopohjalla. He lähettivät minulle biisejä, joihin tutustuin. Alun perin niitä oli parikymmentä.

(Rekinen 2000b.) 
Aiemmille levyille biisit on valittu "demokraattisesti" yhtyeen jäsenten kesken. Nyt sovitaan, että valinnan tekee "diktaattorina" de Courson (Nevalainen 2001). Tuottaja itse muistelee: "Keskustelimme toki bändin kanssa aiheesta, mutta lopulta asia jäi tuottajan harteille. Mielestäni kokonaisuuden kannalta mukaan on kelpuutettu oikeat biisit." (Rekinen 2000b.) Tutustuttuaan demomateriaaliin de Courson valitsee 11 kappaletta mukaan albumille, Äijö näiden joukossa. Äänitysviikoksi sovitaan 22.28.11.1999. Värttinä on treenannut intensiivisesti syyskuun alusta lähtien. Äänitysviikkoa edeltävän kahden viikon ajan levylle tulevia kappaleita harjoitellaan joka päivä. (Nevalainen 2001.)

Viimeistään nyt alkaa myös olla selvää, että loitsun esittäjäksi halutaan vieraileva esiintyjä. Mari Kaasisen sanoin:

Teimme Äijö-biisiä, johon piti saada manausta. Olimme kuunnelleet arkistonauhoista oikeita sellaisia ja totesimme, että kirkasääniset Rääkkylän tytöt eivät moiseen mörinään pysty - -. Äkkäsimme, että Ismolla on hyvä manausääni. Mies tuli empimättä mukaan.

(Rekinen 2000a.)

Äänitykset alkavat ja biisejä tarttuu nauhalle 2-3 päivässä. Äijö odottaa vuoroaan perjantaihin saakka:

Äijö äänitettiin äänitysviikon vikana päivänä eli perjantaina 26.11.1999. Se oli sen päivän eka biisi. Sen jälkeen tehtiin enää Meri. (Emme muuten vietä studiossa koskaan enempää kuin 3-5 äänityspäivää. Siis pohjasoittoon... Lisäksi tulee päällesoittoja ja etenkin laulutuplauksia...) - - Kaikki pyrittiin soittamaan mahdollisimman livenä. Lepistö soitti jouhikonkin livenä. Itse soitin yllättäen kitaraa, mutta heti perään soitin päällesoitossa Cümbüs Tanburia.

(Varilo 2002.)

Kitaran ja cümbüs tanburin osalta Varilo (2002) tarkentaa:

Skitta soittaa lähinnä hypnoottista oktaavi-rytmiä. Se on lähinnä perkussiivisessa roolissa. Cümbüs korvaa kitaran osuuden paikka paikoin ... Itse asiassa olin luopumassa kitaraosuudesta kokonaan, kunnes päädyin soittamaan niukasti ja perkussiivisesti. Ja niinhän mä kai muutenkin teen näissä isoissa yhtyeissä. Tavaraa on jo muutenkin niin paljon.

Tuottaja Hughes de Courson kuvaa rooliaan seuraavasti: "Minä toimin soundimaailman muokkaajana ja annoin suuntaviivoja projektissa" (Rekinen 2000b). Äijössä kuultava pianon kielien rapistelu onkin alun alkaen nimenomaan de Coursonin idea. Varilo (2002) kertoo:

Kyllä hän pyrki vahvistamaan uhkaavuutta. Muistaakseni soitimme hänen kanssaan Äijöön Pianon [sic]kieliä. Siis rapsuttelimme niitä Riston [Hemmi] äänittäessä näitä mahtavia soundeja. 
Cümbüs tanburin päällesoittoon liittyen Varilo (2002) muistaa seuraavan tilanteen: "Pyysin Marko Timosta kuuntelemaan ja tuottamaan, kun soitin Cümbüsia. Hughes ei ollut rytmisesti tarpeeksi vaativa. (Ranskalaista joo, joo ihan hyvä-meininkiä.)" Hemmin roolia Varilo (2002) kommentoi: "Normaalin kannustava, eli huippumeininki. Pianon kielien 'tuhoamisesta' hän nautti kovasti. Eli kyllä hän oikein innostui tästä biisistä." Myös tuottajan ja äänittäjän yhteistyö toimii ongelmitta. De Coursonin sanoin: "Äänittäjänä toimi Risto Hemmi, joka teki kaikki tekniset ratkaisut. Miehen ammattitaito ja soundivalmius ovat ällistyttäviä." (Rekinen 2000b.) Hemmi (2002) korostaa kuitenkin, että de Coursonin rooli soundimaailman muokkaajana koski nimenomaan sovituksia, ei äänitysteknisiä ratkaisuja:

Äänittämisen kannalta soundi oli täysin minun vastuullani, Courson ei puuttunut soundeihin mitenkään. Tein itse kaikki mikrofonien asettelut ja sellaiset. Courson oli tyytyväinen soundeihin eikä hänellä ollut niihin huomauttamista. Hänellä oli sovituksia laulu- ja instrumenttiosuuksia - koskevia ideoita ja hän puhui niistä Värttinän kanssa.

Mikrofonien asettelulla onkin tärkeä tehtävä levyltä kuultavan laulusoundin kannalta. Hemmille on vuosia kestäneen yhteistyön tuloksena vakiintunut oma tapansa äänittää Värttinän laulajia:

Värttinän kohdalla äänitän lauluosuudet niin, että jokaisella tytöllä on oma mikki lähellä, johon he laulavat. He seisovat puolikaaressa ja keskellä on stereomikrofoni, joka ottaa kokonaissoundin. Näin saan sekä kunkin tytön äänen erikseen, että kokonaisuuden. Tämä toimii nimenomaan Värttinän kohdalla.

(Hemmi 2002.)

Samaa periaatetta Hemmi (2002) kertoo soveltavansa kuitenkin myös soitinosuuksien kohdalla: "Kyllä, vähän sama instrumenttiosuuksissa. Minulla on mukana tilamikrofoni ja sitten otan jokaisen instrumentin myös omasta mikrofonistaan." Myös naisten lauluosuudet äänitetään studiolivenä - jopa levyltä kuultavien efektien (käärmeen sihinä, huohotus) kohdalla:

Sihinä äänitettiin samalla kertaa kuin muut lauluäänet. Tytöt olivat jakaneet osuuksia niin, että he eivät laulaneet koko aikaa yhdessä vaan jotkut lauloivat eri juttuja kuin muut. Joillakin oli sitten sitä käärmeen sihinää. Mutta kaikki äänitettiin yhdellä kertaa.

(Hemmi 2002.)

Miesten laulamat osuudet sen sijaan dubataan jälkikäteen. Ismo Alangon osalta Hemmi (2002) muistelee: "Alangon osuus äänitettiin erikseen. Muut oli äänitetty jo aikaisemmin, biisi oli muuten jo valmis. Ismo tuli sitten tekemään osuutensa viimeisenä."

Ilmatar miksataan Ranskassa Acousti Paris -studioilla tammikuussa 2000. Kolme kappaletta lähetetään kuitenkin miksattavaksi Suomeen ja ne miksataan Finnvoxin 
studioilla Helsingissä vielä tammikuun aikana. De Courson selittää ratkaisua:

Minulla oli henkilökohtaisia asioita, jotka pakottivat minut lähtemään Ranskaan. Niinpä miksasin levyn kotimaassani. Bändi halusi joitakin omia juttujaan miksaukseen, joten miksausta jatkettiin Suomessa.

(Rekinen 2000b.)

Ilmatar-albumin oheislehtisen mukaan miksauksen tekee Alain Cluzeau avustajanaan Fred Commault. Äänittäjä Risto Hemmi (2002) tarkentaa tapahtumien kulkua seuraavasti:

Kaikki miksattiin ensin Pariisissa. Jotkut näistä miksauksista poikkesivat kuitenkin halutusta ja bändi halusi, että ne miksataan uudestaan. Kivutar on kokonaan minun miksaamani. Se on oikeastaan demo, jonka minä olen miksannut yksin. Sitten on Itkin ja $\ddot{A} i j o ̈$, jotka ovat enempi teoksia ja siksi bändi halusi, että ne miksataan uudestaan. Itkin on miksattu Pekka Lehden kanssa ja Äijön miksasin Antto Varilon kanssa.

Äijön miksauksen yksityiskohtia ja työnjakoaan Varilon kanssa Hemmi (2002) kuvaa seuraavasti:

Äijössä muutettiin eri elementtien sisääntuloa ja häivytystä. En nyt muista, minkälainen se alkuperäinen ranskalainen miksaus oli, mutta eri osuuksien sisääntuloa ja häivytystä ihan siinä alussa ne muutokset koski. Antto tiesi säveltäjänä mitä halusi ja sanoi mitä sisään milloinkin. Minä vastasin teknisestä toteutuksesta ja soundista.

Se, mitä Varilo säveltäjänä halusi, oli biisin uhkaavan tunnelman korostaminen miksauksen avulla:

Alkuperäinen - jo soittaessa koettu - energisyys ja uhkaavuus ei tullut esiin Hughesin miksauksessa. Hän itsekin valitteli sitä ja pyysi meitä koettamaan itse. Laitoimme biisin jyräämään!!!

(Varilo 2002.)

Työnjakoaan Hemmin kanssa Varilo (2002) kommentoi:

Ei mitään tarkkaa. Risto on niin hyvä, että kaikki sujuu kuin itsestään. Aina, kun pyysin jotain, hän oli jo tekemässä jotain vastaavaa. Eli ajatukset menivät todella samaa rataa. Visiomme oli sama. Meillä oli ihan pirun hauskaa! Ruokimme toinen toisiamme esim. korostamaan manauksen uhkaavuutta. Laitoimme "nupit kaakkoon".

Kaksikko on tulokseen tyytyväinen ja Äijö masterointia vaille valmis. Pauli Saastamoinen masteroi Ilmatar-albumin Finnvoxin studioilla vielä tammikuun 2000 aikana. 


\section{IImatar: julkaiseminen ja markkinointi}

Valmis Ilmatar-albumi koostuu CD-levystä, levykotelosta sekä 16-sivuisesta oheislehtisestä, jonka kansi toimii samalla levyn kantena. Oheislehtinen sisältää Kari Reimanin löytämän vanhan karjalaisen toisinnon Ilmatar-tarusta sekä kaikkien kappaleiden sanat. Ilmatar-runon englanninkielinen käännös on Reimanin ja manageri Philip Pagen käsialaa, laulujen sanat on englanniksi kääntänyt Mats Hulden. Runo kuuluu seuraavasti:

Lensi Kokko koilta ilman, alta taivon. Liiteli ja lenteli, pesän sijaa etsiskellen. Ilmatar, ilman haltija, kaunis neitsyt, nosti polveansa merestä Kokolle pesän sijaksi. Kokko muni Ilman Immen polvelle kuusi kultaista munaa, rautamunan seitsemännen. Nousi tuuli aivan tuima, vihainen Vihma mereltä ja vieritti munat vetehen. Niin tuli halea hauki, veden koira konkotellen ja nieli munat. Kokko lintu, kurja raukka iski kerran, iski toisen ja halkaisi hauen vatsan. Mikä oli munissa ylistä puolta, muuttui vaskiseksi taivahaksi. Mikä oli alista puolta, rautaiseksi maaemäksi. Mikä munissa ruskiaista, Päiväksi paistamahan, Mikä valkiaista, Kuuksi kuumottamaan. Kuoren sirut tähtösiksi taivahalle.

(Reiman 2001.)

Runossa on yhtäläisyyksiä Kalevalan ensimmäisen runon Ilmatar-episodiin, mutta se yhdistelee siihen aineksia muista Kalevalan runoista (mm. 19, 47 ja 48 runo). Siitä löytyy myös Värttinän kahden edellisen albumin nimet (Kokko ja Vihma), mikä korostaa runolauluperinteen merkitystä ja jatkuvuutta Värttinän musiikissa.

Kannen ja oheislehtisen visuaalinen suunnittelu ja toteutus annetaan Jarin (nitrus. bombsquad.org) tehtäväksi. Jari kuvittaa Ilmatar-runoa kotkan siipisulkia sekä hauen alaleukaa, pyrstöä ja ruotoa esittävillä kuvilla. Äijö nostetaan oheislehtisessä esiin irrottamalla loitsu muusta sanoituksesta erilleen oheislehtisen takakannen sisäpuolelle ja sijoittamalla saman aukeaman vasemmalle puolelle käärmeen luurankoa esittävä kuva. Näin Äijö kytkeytyy konkreettisesti osaksi albumin kalevalaista teemaa.

Ilmatar julkaistaan Euroopassa ja Japanissa BMG:n Wicklow-merkillä toukokuussa 2000. Suomessa julkistamispäivä oli 2.5.2000. BMG päivittää nettisivujensa Värttinä-artistibiografiaa Ilmatar-levyä koskevilla tiedoilla. Ilmatarta koskeva osuus kuuluu seuraavasti:

Vuodelle 2000 Värttinä asetti päämääränsä yhä korkeammalle, tavoitteena kehittyminen ilman kompromisseja. Yhtyeen kahdeksas albumi ILMATAR julkaistaan Suomessa toukokuussa 2000. Levyn tuottajana on eräs Ranskan huipputuottajista, Hughes de Courson, joka tunnetaan mm. levyistään Songs of Innocence (EMI), Lambarena (Sony), Palestrina (Detour), Mozart in Egypt (Virgin), Spondo (Melodie), Lebrijanon Lagrimas de Cera (EMI) sekä legendaarisesta Malicorne-yhtyeestään. ILMATAR-levyn soivituksissa [ $\mathrm{sic}]$ ja tuotannossa oli tavoittena saada Värttinän soinnista ilmavampaa ja "tilavampaa" sekä jatkaa jo Vihmalla alkanutta lauluäänien monipuolistamista 
sekä sooloissa että kuoro-osuuksissa. Myös rytmisoittimiin kiinnitettiin erityistä huomiota.

ILMATAR on ilman jumalatar vanhoissa suomalaisissa runolauluissa ja Ilmatar on levyllä vahvasti läsnä niin levyn nimessä kuin äänimaailmassakin. Levyn laulut vaihtelevat herkästä ja kauniista Mari Kaasisen laulamasta "Miljasta" villiin ja synkkään "Äijöön", jossa vierailee shamaanina Ismo Alanko. Ranskalaisen Gilles Chabenatin kampiliira antaa lisäväriä useille levyn raidoista. Kaiken kaikkiaan ILMATAR on levy, joka tulee sävähdyttämään ja yllättämään sekä vanhat uskolliset Värttinän seuraajat että uudet Värttinä-musiikin ystävät.

Värttinä lähtee kiertueelle ILMATAR-levyn ilmestymisen myötä ja odotettavissa on esiintymisiä Japanissa, Yhdysvalloissa, Espanjassa, Ranskassa, Unkarissa, Itävallassa, Belgiassa, Saksassa, Italiassa, Tsekissä, Ruotsissa ja tietysti Suomessa. (Clic2 Music 2001.)

Tiedote korostaa kalevalaista Ilmatar-teemaa ja mainitsee tässä yhteydessä "villin ja synkän" Äijön, jossa "vierailee shamaanina Ismo Alanko". Näin tiedote entisestään vahvistaa levykotelon kuvaa Ilmattaren ja Äijön kiinteästä yhteydestä suomalais-ugrilaiseen runoperinteeseen.

Uuden Värttinä-albumin ilmestyminen ylittää uutiskynnyksen. Värttinä on Rytmilehden numeron 3/2000 kansikuvayhtye ja lehden sisäsivuilta löytyy Jyrki Rekisen reportaasi, jossa hän haastattelee Kari Reimania ja Mari Kaasista (Rekinen 2000a), tuottaja Hughes de Coursonia (Rekinen 200b) sekä manageri Philip Pagea (Rekinen 2000c). Samassa numerossa ilmestyy myös Kari Hämekosken (2000) ylistävä Ilmatar-arvostelu. Kansanmusiikkilehti Friiti julkaisee numerossaan 1/2000 Esa Mäkisen (2000) kirjoittaman artikkelin, joka perustuu Kari Reimanin haastatteluun. Hannu Lehtorannan Ilmatar-arvostelu ilmestyy Friitin numerossa 3/2000. Arvosteluun sisältyy myös Äijö̈ koskeva maininta:

Muita mausteita sinällään rikkaaseen bändisoundiin tuovat mm. Gilles Chabenat'n kampiliira ja Ismo Alangon messuama tuttu Käärmeelle-loitsu, joka on upotettu Äijön sisälle.

Ilmatar on erilainen Värttinä-levy - siitä puuttuu se rankimman vaiheen kovaa ja korkealta kailottaminen. Vääntöä löytyy silti, esimerkiksi juuri edellä mainitusta Äijöstä.

(Lehtoranta 2000: 50.)

Karjalaisessa ilmestyy vapunaattona 2000 Kimmo Nevalaisen kirjoittama juttu, jota varten Nevalainen on haastatellut Kari Reimania ja Mari Kaasista. Juttuun sisältyy myös Nevalaisen Ilmatar-arvostelu. Äijöä Nevalainen (2000) kommentoi seuraavasti:

Niin, Värttinä osaa edelleenkin olla myös herkkä, mutta myös aivan muuta. Aijö [sic] ja Kivutar ovat melkoista rypistystä. Äijö lepää shamanistisessa tunnelmassa ja muutaman mahdottoman tehokkaan riffin varassa, Kivuttaressa on täysin älytön tahtilaji 37/8, mutta lisäksi Kari Reimanin viulut lähestyvät biisissä jo kamarimusiikkia ja -jazzia. 
Helsingin Sanomat julkaisee Värttinästä ison jutun levyn ilmestymispäivänä 2.5.2000. Juttu koostuu Pirkko Kotirinnan (2000a) kirjoittamasta tausta-artikkelista, Ilkka Mattilan (2000) tekemästä Mari Kaasisen ja Antto Varilon haastattelusta sekä Kotirinnan (2000b) Ilmatar-arvostelusta. Arvostelun Äijö-kommentit kuuluvat seuraavasti:

Äijö-biisissä naislaulajien saundi kohtaa Ismo Alangon muhevan kähisevän manauk-
sen ja kas: ugrilainen alkuvoima on käsinkosketeltavampaa kuin koskaan. Kirkkaan
Värttinä-saundin ja Alangon syvän örinän yhdistelmä toimii valovuosia paremmin
kuin Vihman kokeilu yhdistää Värttinä-saundi tuvalaiseen kurkkulauluun.

(Kotirinta 2000b.)

Suomen Kansanmusiikkiliiton uutuusarvioissa Ilmattaren arvostelee Marjo Jääskä. Äijöä koskevat kommentit ovat linjassa muiden kotimaisten arvostelijoiden käsitysten kanssa:

Alangon panos Ilmattarella on Äijö-nimisen kappaleen keskelle sijoitettu käärmeen loitsu. Alangon mörinä toimiikin sävelmässä loistavasti. Loitsiminen laajentaa tunnelmaa, eikä mörinä kuulosta yhtään päälleliimatulta.

(Jääskä 2002.)

Kaiken kaikkiaan arvosteluissa korostetaan Äijön suomalais-ugrilaisia ulottuvuuksia: "ugrilaista alkuvoimaa", shamanistista tunnelmaa ja loitsun merkitystä tunnelman laajentajana.

Euroopassa kriiitikoiden ensireaktiot ovat Nevalaisen (2001: 81) mukaan "myönteisemmät kuin koskaan". Christian ja Michael Moll arvostelevat albumin saksalaisessa FolkWorld-nettilehdessä. Negatiivista sanottavaa he löytävät ainoastaan Ismo Alangon osuudesta Äijössä:

Minulle albumin ainoa pohjakohta on yhteistyö suomalaisen rocklaulaja Ismo Alangon kanssa, "Äijö", mutta epäilemättä kysymyksessä on makuasia. Ilamatar [sic] osoittaa Värttinän menevän hyvin positiiviseen ja jännittävään suuntaan; silti se osoittaa jälleen kerran, että et voi koskaan tietää mitä odottaa tämän erityisen bändin uudelta albumilta. Ihana $\mathrm{CD}$.

(Moll \& Moll 2000.)

Englantilainen Folk Roots julkaisee Andrew Cronshaw'n kirjoittaman Ilmatar-arvostelun lokakuun 2000 numerossaan. Äijöstä Cronshaw kirjoittaa:

Äijössä - suositun suomalaisen rocklaulaja Ismo Alangon loihtimine loitsuineen - on jotakin, minkä voisi katsoa sivuavan Hedningarna-tyylistä lähestymistapaa, mutta kysymys on vain kahden polun risteämisestä pyrittäessä kehittämään ja laajentamaan luonnollisia ja jännittäviä tapoja tulkita tätä alkukantaista, päällekäyvää runo-musiikkia, joka on ollut myös yksi Hedningarnojen laulumateriaalin lähtökohdista. Tässä ei ole polskaa eikä hallingia, tämä on suomalais-ugrilaista, ei skandinaavista, ja perusinstrumentaatioltaan (joka tällä raidalla käsittää jouhikon, hevosenjouhikielisen jou- 
sella soitettavan lyyran) samoin kuin yleissoundiltaan nämä kaksi bändiä ovat eri teillä.

(Cronshaw 2000.)

Toukokuussa 2001 Folk Roots julkaisee Cronshaw'n (2001) kirjoittaman Värttinä-artikkelin. Myös artikkelissaan Cronshaw tarkastelee Värttinän musiikkia suomalais-ugrilaisen perinteen uudelleentulkinnan näkökulmasta.

Ilmattaren tie Yhdysvaltain markkinoille on mutkainen. Värttinä törmää musiikkibisneksen armottomiin lakeihin, kun BMG-yhtiö lopettaa BMG Classics -merkin kannattamattomana ja tätä myötä kaatuu myös Wicklow. Tilanteesta selvitään, kun Värttinä hankkii levyn julkaisulisenssin itselleen ja niin Ilmatar julkaistaan lopulta pohjoismaisen maailmanmusiikin levittämiseen erikoistuneella NorthSide-levymerkillä helmikuussa 2001. NorthSiden tiedottamista ja sen reagointia Ilmatar-albumin vastaanottoon havainnollistaa levy-yhtiön uutispalstallaan alkuvuonna 2001 julkaisemat Värttinä-uutiset (NorthSide 2003c):

05.01.2001 Lue ranskalaisen folk-rock-bändi Malicornen jäsenen ja Värttinän uuden Ilmatar-CD:n tuottajan Hughes de Coursonin haastattelu www.rootsworld.comsivulta. NorthSiden julkaisua albumista odotetaan malttamattomasti - se on kaupoissa 13 helmikuuta.

16.01.2001 Juuri lisätty verkkosivulle: Värttinän uusi albumi ja päivitykset kiertuesivulle.

07.02.2001 Värttinän Ilmatar arvosteltu CMJ:ssä: "Vaikuttava tour de force, sen henkeäsalpaavat naisäänet liitelevät korkealla alati muuntuvan instrumenttitaustan yläpuolella."

16.02.2001 Tiistaina 27 helmikuuta Värttinän Ilmatar on Globaali hitti Public Radio Internationalin The World -ohjelmassa.

02.04.2001 CMJ:n New Music Montlyssa on haastattelu Värttinästä.

14.08.2001 Värttinän esiintyminen vuoden 2001 Nordic Roots -festivaalilla on nähtävissä Minneapolisin julkisella kaapeli-TV:ssä lauantaina 18 elokuuta klo 20.30 ja sunnuntaina 26 elokuuta klo 22.00 .

Ilmatar-albumia koskevan promootiosivun NorthSide perustaa 16.1.2001. Sivun rakenne koostuu levy-yhtiön käytännön mukaisesti seuraavista osioista: albumin kuvaus, arvostelusitaatit (päivitettävä osio), levyn raidat (mukana soivat näytteet muutamasta kappaleesta) sekä bändin edustamaa genreä, maata ja instrumentaatiota koskeva data. Albumin kuvaus kuuluu seuraavasti:

Suomen tämän hetken innovatiivisin ja jännittävin roots-pohjainen bändi räjähtävine lauluosuuksineen ja kuusimiehisine orkestereineen on tullut takaisin uudella julkaisullaan.

Suomalaisessa luomismyytissä, "Kalevalassa", Ilmatar on ilman jumalatar. Hän on luonut taivaan ja maan rikkomalla kaksi Kokko-kotkan hänelle tuomaa munaa. Ilmattaren laulut vaihtelevat energisistä mietiskeleviin, uhkaavista iloisiin - kaikki kiedottuna säkenöiviin laulusuorituksiin, jotka ovat Värttinän syvin olemus. 
Tämä on kiistatta Värttinän tähän saakka paras ja kokeilevin albumi, dramaattinen hyppy eteenpäin. Se sisältää uskomattoman mielikuvitusrikasta akustisten instrumenttien ja lyömäsoitinten käyttöä. Tuottaja Hughes De Courson (ranskalaisen folk/rockbändi Malicornen entinen jäsen) hankittiin antamaan bändille tuore soundi.

Kirpeät sovitukset korostavat bändin vahvuuksia: dramaattisia vokaaliharmonioita ja virtuoottisia instrumentaalisuorituksia.

Ilmatar on bändin kahdeksas albumi sen lähes 20-vuotisessa historiassa, sitä markkinoi Pohjois-Amerikan ulkopuolella BMG. Ilmattarella bändi tulkitsee vuoden 1997 Kokko-albumilla (Nonesuch/WEA) aloittamaansa ja Vihma-albumilla (1998, Wicklow/BMG) jatkamaansa karjalaista runotraditiota vielä pitemmälle [kuin näillä albumeilla].

(NorthSide 2002a.)

Levytiedote korostaa Värttinän asemaa suomalaisen maailmanmusiikin kentässä, taustoittaa albumin kalevalaista Ilmatar-teemaa ja viittaa Kokko- ja Vihma-albumien kautta runolaulutradition ja sen uudelleentulkinnan jatkuvuuteen Värttinän musiikissa.

Avainasemassa Ilmatar-albumin yhdysvaltalaisen vastaanoton kannalta on James Lienin (2001) CMJ-lehdessä 5.2.2001 ilmestynyt ennakkoarvostelu:

On varman päälle pelaavia perinneartisteja ja sitten on niitä, jotka eivät pelkää tunkeutua uusille alueille ja luoda jotakin uutta vanhoista rakenteista. Värttinä on epäilemättä omistautunut jälkimmäiselle ja heidän tekemänsä musiikki kuuluukin kaikkein merkittävimpiin aikamme folkartistien joukossa. Lähes kahden vuosikymmenen ja lukuisien kokoonpanojen jälkeen tämä suomalainen ryhmä jaksaa kiihottaa ja kiinnostaa - jokainen albumi onnistuu jotenkin olemaan edeltäjäänsä kunnianhimoisempi. Ilmatar (nimetty ilman jumalattaren mukaan) ei ole poikkeus. Vaikuttava tour de force, jonka henkeäsalpaavat naisäänet liitelevät korkealla alati muuntuvan instrumenttitaustan yläpuolella.

Myös Lien korostaa arvostelussaan jatkuvuuden ja muuntelun teemaa Värttinän musiikissa.

Ilmatar julkaistaan 13.2.2001. Samana päivänä VH1.COM-onlinelehti julkaisee Chris Nicksonin artikkelin (Nickson 2002a), jossa tämä kertoo Ilmattaren julkaisuvaikeuksista ja haastattelee Kari Reimania. Nicksonilla on muutenkin merkittävä rooli Ilmattaren tunnetuksi tekemisessä, sillä hänen kirjoittamiaan Ilmatar-arvosteluja julkaisevat mm. All Music Guide (Nickson 2002b), Amazon.com (Nickson 2002c) ja ranskalainen Mondomix (Nickson 2003). Tämän lisäksi Nickson kirjoittaa Värttinästä artikkelin Sing Out! -maailmanmusiikkilehteen (Nickson 2002d). Äijöä Nickson (2002b) sivuaa AMG:1le kirjoittamassaan arvostelussa seuraavasti:

Levyn aihe huomioon ottaen ei ole järin yllättävää, että se on albumi magiikasta - aina 'Äijön' manausloitsuun saakka, ja neljän laulajan kirkkaat äänet ja harmoniat leikkaavat ilmaa ihanien noitien tavoin. Musiikillisesti he nojaavat paljolti akustisiin soittimiin (kuten he ovat tehneet ennenkin) luomatta kuitenkaan taustaa, joka kuulostaisi kansanmusiikilta - pitkäaikainen viulisti Kari Reiman ja muut ryhmän jäsenet ovat yksinkertaisesti liian hyviä siihen. 
Christina Roden arvostelee Ilmattaren The Village Voice -lehdessä. Arvostelu julkaistaan myös www.rootsworld.com-sivuilla. Äijöä Roden (2002) kommentoi seuraavasti:

\begin{abstract}
'Äijö' kuvaa puolihullua vanhaa miestä, joka selviää käärmeenpuremasta maagisten loitsujen, viisaasti käytetyn huonon viinan ja silkan pahan sisunsa avulla. Hänen tarinansa kertovat naisäänet, jotka vuorottelevat raivokkaan mörisevän miesäänen kanssa, joka palaa päättääkseen albumin uusilla kirouksilla ja loitsuilla.
\end{abstract}

Maaliskuussa levy nousee CMJ:n maailmanmusiikkilistan ykköseksi. Kesällä yhtye on kahden keskeisen amerikkalaisen lehden (Global Rhythm, kesäkuu 2000; Sing Out! Kesä '01) kansikuvassa ja molemmissa lehdissä on Värttinää käsittelevä artikkeli. NorthSide ottaa arvosteluista ja artikkeleista kaiken irti - 19.9.2002 Ilmatar-albumin promootiosivulta löytyy kaikkiaan yhdeksän sitaattia eri arvostelijoilta (mukana mm. sitaatit Lienin, Rodenin ja Cronshawn'n arvosteluista). Myös levyjen vähittäiskauppa (mm. Amazon.com ja Barnes \& Noble) käyttää markkinoinnissaan hyväkseen toisaalla julkaistuja arvosteluja.

\title{
6.12. (Live in Helsinki): tuotanto, markkinointi ja julkinen vastaanotto
}

Värttinä aloittaa Ilmatar-promokiertueen kesäkuussa 2000. Kiertue suuntautuu BMG:n levytiedotteessa mainittuihin maihin. Äijö on alusta alkaen mukana setissä ja siitä muodostuu nopeasti yksi Värttinän lavabravuureista. Ilmattarella madonluvut luki Ismo Alanko, live-keikoilla loitsun esittäminen lankeaa luonnostaan laulun sanoittaneen Kirsi Kähkösen tehtäväksi. Kähkönen itse kommentoi Alangon saappaisiin astumista seuraavasti:

Kukin tekee tyylillään. Omaltahan se tuntui, kun oli sen tekstin kirjoittanut. Ensin sitä pelkäsi, että tulee black outeja ja unohtaa sanat kesken esityksen ja vähän eri tavalla se eri esityksissä tulikin, mutta kyllä siihen sitten löysi rytmin, jolla se meni.

(Kähkönen 2002.)

Värttinä on jo pitkään suunnitellut live-levyn tekemistä. Kari Reimanin sanoin: "Sitä on pyydetty meiltä melko paljon. Kenties seuraavaksi teemme greatest hits -tyyppisen live-levyn.” (Rekinen 2000a.) Itse asiassa live-levyn mahdollisuus oli ollut esillä jo ennen Ilmatar-projektia, mutta tuolloin Värttinä vielä kuitenkin päätyi studioalbumiin (Rekinen 2000a).

Itsenäisyyspäivänä 2001 Värttinä konsertoi Helsingissä Savoy-teatterissa. Keikka on periaatteessa kuin mikä tahansa kotimaan esiintyminen - sillä erotuksella, että osa yhtyeen jäsenistä on päättänyt, että esitys äänitetään tulevaa live-albumia varten. Kimmo Nevalainen $(2001,87)$ kertoo: 
Jotta laulajat eivät suotta ottaisi nauhoituksesta ylimääräisiä paineita, pää-äänittäjänä toimiva Pekka [Lehti] jättää asian kertomatta laulajakvartetille. Pääsoundi äänitetään bändin omista pa-kamoista, äänityslaitteet ovat miksauspöydällä ja lisäksi ääntä otetaan myös yleisön joukosta.

6.12.-albumin levykannen sisältämien tietojen mukaan Pekka Lehti on session tuottaja, äänittäjänä toimii Miikka Huttunen.

Ilmatar-albumilla Äijö sisältää päällekkäisäänityksiä ja äänitehosteita (mm. pianon kielien rapsuttelua). Koska jokaisella bändin jäsenellä on oma tehtävänsä biisissä eikä vierailevia muusikoita haluta käyttää, sovitusta on yksinkertaistettava ja muutettava vastaamaan yhtyeen kokoonpanoa. Ilmeisin muutos on, että Kirsi Kähkönen korvaa Ismo Alangon loitsun esittäjänä. Sovitusta on pantu uusiksi kuitenkin myös muiltakin osin. Intron avantgardistinen osuus venyy nyt yli puolen minuutin mittaiseksi. Myös vokaali-intro on sovitettu uudelleen: naisäänet ovat nyt miesäänten tilalla ja äänten sisääntuloa on niinikään muutettu alkamaan synkronisesti instrumentaalitaustan kanssa. Häivytykset luonnollisesti puuttuvat.

Värttinä on tyytyväinen keikkaan ja äänitykseen. Alkuvuodesta 2001 päätetäänkin, että live-levy tehdään vain tältä yhdeltä keikalta. Osasyynä tähän on, että Riikka Timonen on jättämässä yhtyeen ja näin konserttitaltioinnilla on ylimääräistä dokumenttiarvoa yhden aikakauden päätöksenä. (Nevalainen 2001: 87.) Miksauksen tekevät Risto Hemmi ja tuottajana toimiva Pekka Lehti Finnvoxin studioilla 7.-11.5.2001. Bändin tavoittelema dokumentaarinen ote pyritään säilyttämään myös miksauksessa. Hemmin (2002) sanoin:

6.12. on siitä harvinainen live-levy, että se on oikea live - että siihen ei ole lisätty mitään. Se on sillä lailla dokumentaarinen. Yleensähän live-levylle lisätään jälkeenpäin jotakin, esimerkiksi lauluosuudet. 6.12. on oikea live-levy, se on tarkoitettu dokumentaariseksi.

Miksauksessa tavoitetaan sama avaruudellisuuden tuntu kuin Ilmattarellakin. Hemmin ja Lehden työnjako toimii periaatteessa samalta pohjalta kuin Hemmin ja Varilon työnjako Ilmatar-albumilla. Pauli Saastamoinen masteroi levyn Finnvoxila 31.5.2001.

Heinäkuussa tehdään Aijöstä vielä video, joka päätetään sisällyttää bonusraitana 6.12.-albumille. Tuottajana toimii Sökö Kaukoranta (yhdessä manageri Phillip Pagen kanssa). Esitys kuvataan Nosturissa. Ääniraitana käytetään Savoy-teatterissa 6.12. 2000 äänitettyä live-esitystä, jota Värttinä imitoi playbackina. Antto Varilo (2002) kommentoi epätavallisen ratkaisun taustaa seuraavasti: 'Live-versio on loistava. Halusimme tehdä videon ja mielestämme tämä oli jotain uutta: playback live-versiosta!!! Hauskaa. Pöhköä!” Videon ohjaa Sökö Kaukoranta. Lopputulosta voisi luonnehtia musiikkilähtöiseksi konserttivideoksi (vrt. Kurkela 2001: 102-104; Kärjä 1997: 187). Konserttitaltiointina se on samanaikaisesti sekä dokumentaarinen konserttivideo että playbackvideo: ääniraitana on Savoy-teatterissa 6.12.2000 äänitetty live-esi- 
tys, kuvana taas tästä esityksestä heinäkuussa 2001 Nosturissa ilman yleisöä tehty playbackimitaatio. Musiikkilähtöinen se on sikäli, että kuvan ensisijaisena tehtävänä on tukea musiikin rakennetta ja sanomaa leikkauksen, kameraliikkeiden ja valaistuksen avulla. Leikkaus ja kameraliikkeet seuraavat pääsääntöisesti sitä laulajaa, muusikkoa, ryhmää tai sen osaa joka parhaillaan esittää jotakin. Valaistus (sininen, punainen ja vihreä taustavalo, psykedeelinen valomosaiikki, valkoinen spottivalo) tukee musiikkia ja jäsentää esitystä. Videon editoinnista vastaa Sökö Kaukoranta, kameratyöstä Pasi Takala (assistenttina Vesa Rahkola) ja valaistuksesta Juha Westman (assistenttina Lauri Hakoniemi).

Elokuussa 2001 BMG Finland julkaisee uuden painoksen Ilmatar-albumista, nyt - Wicklown kaaduttua - RCA-merkillä. BMG ilmoittaa asiasta julkaisutiedotteessa 34/2001 (BMG 2002a) ja kertoo samalla, että live-levy 6.12. ilmestyy syyskuun alussa. Seuraavassa uutuustiedotteessaan (35/2001) BMG (2002b) sitten jo hehkuttaakin albumin suomalaista teemaa:

6.12. on suuri ylistys suomalaiselle perinteelle, suomalaiselle musiikille ja suomalaiselle asenteelle. Värttinä on urallaan saavuttanut suurta suosiota ympäri maailmaa tinkimättömällä tyylillään. He ovat esiintyneet pienissä klubeissa ja isoilla festivaaleilla valloittaen kuulijansa kielimuureista tai kulttuurieroista välittämättä. Uudella levyllä Värttinä esiintyy elävän yleisön edessä Helsingin Savoy-teatterissa 6. joulukuuta vuonna 2000. Mukana on yhtyeen parhaita biisejä sekä bonuksena lisäksi video Äijöstä.

Syksyllä 2001 Värttinä uudistaa täysin verkkosivunsa. Sivujen uusimisesta vastaavat Timo Lehtinen ja Philip Page. Uutisten, bändiesittelyn, levytysten, kuvagallerian, konserttiohjelman, biografian, diskografian lisäksi mukana on myös oma sivunsa Ä̈ijövideolle. Sivu sisältää still-kuvan videon alusta, lyhyen esittelyn sekä mahdollisuuden kuunnella video ja ladata se omalle tietokoneelleen. Videon esittely kuuluu seuraavasti:

Värttinän kolmas video on live-versio "Äijöstä", [joka on] alun perin ilmestynyt stu-
dioäänityksenä heidän viimeisellä albumillaan Ilmatar. Värttinä-kitaristi Antto Vari-
lon säveltämä ja Kirsi Kähkösen sanoittama laulu on yksi bändin vahvimmista lava-
numeroista. Se kertoo tarinan hullusta vanhasta Äijö-ukosta, jota on purrut käärme,
ja joka turvautuu muinaiseen loitsuun vapautuakseen itsensä myrkystä ja käärmeen
koko olemassaolosta. Ilmatar-albumilla arvostettu rocklaulaja Ismo Alanko vierailee
"Äijönä", kun taas lavalla ja videolla Kirsi sähisee loitsun mahtavan vaikuttavalla ta-
valla. "Äijö"-video, [joka on] myös bonusraitana 6.12-CD:llä, esittelee uuden Värtti-
nä-laulajan Johanna Virtasen, joka korvaa Riikka Timosen, ja perkussionisti Jaska
Lukkarisen, joka korvaa Marko Timosen.

(Värttinä 2002a.)

Myös Kimmo Nevalaisen Värttinä-biografian (2001) voi osaltaan katsoa olevan osa 6.12.-albumin promootiota. Kirja ilmestyy Suomessa jokseenkin samanaikaisesti livelevyn kanssa, sen etu- ja takakannen kuvitus käy yksiin 6.12.-albumin kannen kuvien 
kanssa ja kirjan nuottiosio sisältää kaikki 6.12.-albumin kappaleiden nuotit (tämä on ollut yksi nuotteina julkaistujen kappaleiden valintaperuste).

Rytmi-lehdessä 6.12.:n arvostelee Kari Hämekoski, joka positioi arvostelunsa "tunnustukselliseksi keikka-arvioksi” (Hämekoski 2002). Hän ei ole ollut itsenäisyyspäivänä läsnä Savoy-teatterissa, mutta on kuullut Värttinää aiemmin syyskuussa Helsingin juhlaviikoilla. Arvostelu peilautuu tätä kokemusta vasten:

Huvilateltta. Syyskuu 2001. Toimittajanne istuu uupuneena takarivissä. ’Täytyy muutama biisi katsoa, sounditkin ovat niin kohdallaan.” Mutta illan päättyessä toimittaja löydetään aivan eturivistä. Hän on silminnähden erittäin innostunut kokemastaan. Esitys on vaikuttanut häneen kaikkein [sic] aistein. Tämä levy toistaa toimittajan kokemuksen. Ei ehkä sittenkään aivan yhtä irtonaisena; hetkittäin eturivi tööttää melkoisesti ja Meri-biisin tematiikan käsittely jää kesken. Mutta levy on vaikuttanut häneen suuresti. $5 / 5$.

(Hämekoski 2002.)

Saksalaisen, lähinnä opiskelijoille suunnatun Holterdipolter Musik Magazinin arvostelija Nico Steckelberg (2002) puolestaan erittelee kokemuksiaan Äijöstä seuraavasti:

Minulle Värttinää ensikuulijana tulevat mieleen lähinnä kaakattavat kanat, etenkin kun näiden neljän nuoren naisen äänet eivät juuri toisiaan pehmennä vaan kuulostavat usein korkeilta, kimakoilta, kirkuvilta ja toisinaan jopa suorastaan vihaisilta. Näin on esim. avausraidan "Äijö" kohdalla - laulun, joka (oheislehtisen mukaan) käsittelee sekopäistä vanhaa miestä, jota käärme on purrut. En kyllä ymmärrä tarinasta yhtään sanaa, mutta Kirsi laulaa tai huutaa yleisön edessä sen verran energisesti, että tässä ihan pelkää, että tämä käärmeenpurema tyyppi tulee Suomessa lomailijaa tiellä vastaan - niin kirotun katkera hänen täytyy olla.

Kiinnostavaa artikkelissa on tapa, jolla Steckelberg tarkastelee Äijöä suhteessa saksalaisten Suomeen suuntautuvaan villi pohjola -henkiseen turismiin. Tämä näkökulma säilyy, kun Steckelberg kommentoi (2002) lyhyesti myös Äijö-videota:

Pienenä yllätyksenä on CD:1lä Äijö-laulusta myös live-video, jossa korvanherkusta tulee silmäniloa. Ja minä varoitan teitä: He [Suomessa lomailijat] tulevat kyllä pelkäämään sitä käärmeenpuremaa tyyppiä entistäkin enemmän, kun he näkevät nuo neljä energistä laulajatarta laulamassa.

Matkailun, turismin ja Suomi-kuvan kontekstissa liikutaan edelleen, kun Finnairin Blue Wings (Europe) -lehti julkaisee helmi-maaliskuun 2002 numerossa Wif Stengerin kirjoittama artikkelin Värttinästä. Artikkeli alkaa Äijöä koskevalla kuvauksella:

Värttinän uusi live-CD, nimeltään 6.12., alkaa hillittömällä metelillä. Kun toisesta maailmasta peräisin olevat instrumentit kirskuvat ja vingahtelevat demonisesti, vokalisti Kirsi Kähkönen alkaa kähisevän laulun, kehien kertomusta vanhasta shamaanis- 
ta nimeltä "Äijö”, joka vuodattaa hirvittävän kirouksen käärmeelle puutarhassaan. Kun Kähkösen ääni kohoaa hulluuteen asti, kolme muuta laulajaa tulevat hänen taustakseen Macbethin hullujen sisarten tavoin. Vaikutelma on jännittävä ja jotakin sellaista, mitä ei ole koskaan ennen levytetty.

(Stenger 2002: 24.)

Yhdysvalloissa live-albumi julkaistaan NorthSiden toimesta 12.3.2002 nimellä Live in Helsinki. Levy-yhtiön verkkosivulla oleva albumin kuvaus kuuluu seuraavasti:

Suomen Värttinä on tullut tunnetuksi ympäri maapalloa upeiden naislaulajiensa ja perinteeseen pohjaavien progressiivisten sovitustensa ansiosta. Live in Helsinki, Värttinän 9. julkaisu, sisältää muutamia heidän yleisönsä suosikkeja viimeisen vuosikymmenen ajalta - mukaan lukien heidän varhaisia klassikkojaan, jotka on sovitettu uudelleen ylimääräisen potkun aikaansaamiseksi. Tämän 10-päisen ryhmän dynaamiset instrumentti- ja vokaalisuoritukset loistavat tällä heidän ensimmäisellä live-albumillaan.

Äänitetty live-konsertissa 6. joulukuuta 2000 Helsingissä, Suomessa. Ylimääräisenä hyvänä CD sisältää "Äijö"-videon ja bändiä koskevaa lisäinformaatiota.

(NorthSide 2002b.)

Live in Helsinki -sivun arvostelusitaattiosiossa NorthSide lainaa edellä siteeratun katkelman Wif Stengerin artikkelista.

Kritiikeistä huomionarvoinen on Bob Tarten Miami New Times -lehdessä 2.5.2002 ilmestynyt arvostelu (Tarte 2002a), joka sisältyy myös Tarten The Beat -lehden numerossa 3/2002 julkaisemaan laajempaan Technobeat-kolumniin (Tarte 2002b). Tarte (2002a) kirjoittaa:

Kuvittele 1970-luvun ruotsalaista popryhmää Abbaa täydessä ekstaattisessa tiltissä keskellä kiihkeää kertosäettä. Ota se lähtökohdaksi, jonka pohjalta Susan Aho, Mari Kaasinen, Riikka Timonen ja umlauteilla siunattu Kirsi Kähkönen aloittavat, lisäävät riitasointuisia harmonioita, itämaisia modaliteetteja, ja viimeistele kvartetti enkelipölyllä - oikeilta enkeleiltä pudonneella, ei sillä huumeella - päästäksesi jyvälle näiden naisten luonteesta.

Live-levyn laulut tavoittavat Värttinän tuottamassa kaikkein primitiivisimmällä tavalla pakanallista soundia, jota voi tavata missään popmusiikissa - kärisevän, kähisevän, estrogeeniä tihkuvan estetiikan, joka juontaa aina arkaaisiin vedenpaisumusta edeltäviin päiviin ennen maan napojen kääntymistä ylösalaisin, kun matriarkaalisuus oli vielä voimissaan.

Äijöä Tarte (2002a) arvioi seuraavasti:

Levyn avaavalla "Äijöllä” kvartetti naispaholaisia nousee sähisten kolostaan, kun Kähkönen sylkee ilmoille muinaisen käärmeen loitsun niin pimeältä keskiaikaiselta alueelta, että edes Grimmin veljekset eivät olisi uskaltaneet kertoa moista juttua. Se on standardisuomea, mutta Kähkönen on valinnut kaikkein kidutetuimmat äänteet, jotka hän on vain saattanut löytää tehdäkseen runosta entistä herjaavamman. 
Arvostelun päättää $A \ddot{i} j o ̈$-videota koskeva kommentti:

Olet viimeisen päälle väsytetty, tuskin kykenet työntämään CD:n PC:si sisään katsoaksesi levyllä olevan loistavan mutta levottoman konserttivideon "Äijöstä". Mutta mitä ikinä teetkin, älä vain jätä CD-soitintasi toistoasentoon tai tarvitaan ryhmä henkiparantajia lausumaan jotakin munkkilatinaa kuten veroilmoitustekstiä, jotta sinut saisi takaisin mihinkään, mikä on lähellä normaalia tietoisuutta.

(Tarte 2002a.)

Tarten arvostelusta löytyvät sellaisenaan tai lähes sellaisenaan kaikki ne elementit, joilla Antto Varilo on kuvannut biisin lähtökohtana ollutta tunnelmaa: uhka, yliluonnollinen tapahtuma, transsi, pelko ja keskiaika. Edelleen, Steckelbergin, Stengerin ja Tarten arvioiden perusteella Kirsi Kähkösen voi katsoa onnistuneen loitsun esittämisessä - niin live-esityksessä 6.12.2000 että tuon esityksen imitoimisessa Nosturissa heinäkuussa 2001 - jokseenkin täydellisesti, niin yksimielisiä kirjoittajat ovat esityksen vaikuttavuudesta. Puhe siitä, että loitsun esittäminen ei onnistu "kirkasäänisiltä Rääkkylän tytöiltä” oli ennenaikaista ja vahvasti liioiteltua.

\section{Äijö: fanipalaute Värttinä Forum -palstalla}

Joulukuussa 2001 Värttinän virallisilla verkkosivuilla käynnistyy rekisteröityjen jäsenten keskustelupalsta (Forum), joka on kuitenkin kaikkien asiasta kiinnostuneiden selattavissa. Forum on jaettu erikseen varsinaiseen keskustelupalstaan (discussion) ja albumeja koskevaan osaan (albums). Sekä keskustelu- että albumiosuus on jaettu aihepiireittäin kansioihin. Äijöön liittyviä kommentteja löytyy lähinnä 6.12.-albumia sekä suomalais-ugrilaista musiikkia ja kulttuuria koskevista kansioista.

Live-albumia koskevan keskustelun käynnistää etelä-korealainen nimimerkki "bokmal" 29.12.2001. Muutamien albumia yleisemmin luonnehtivien kommenttien jälkeen suomalainen Vihmaaja aloittaa Äijöä (Ilmatar, live-audio, video) koskevan keskustelun, joka aluksi etenee hänen ja unkarilaisen Sandorin välisenä kaksinpuheluna:

VIHMAAJA [13.01.2002, 12:02]: "Joo, luulen, että siinä on yksi juttu, jota todella VIHAAN... Äijö! Tämä laulu oli "Ilmattarella" niin pelottava ja uhkaava. Mutta livealbumilla se on köykäinen ja... miten sen osaisin sanoa? Iloinen :०”

SANDOR [13.01.2002, 19:08]: "Eikö live-Äijö ole pelottava? Minusta asia on juuri päinvastoin. Kirsi tekee manauksen niin hyvin konserteissa ja videolla, että ehkä se on liiankin pelottava, sillä pidän hänestä paljon enemmän nätisti hymyilevänä."

VIHMAAJA [16.01.2002, 17:54]: ”Joo, tietenkin Kirsi tekee parhaansa, mutta musiikki on liian kevyttä. Ei sillä, ettenkö pitäisi myös "kevyestä" musiikista, mutta Äijö oli ennen PELOTTAVA! Ja videoversio kuulostaa vähän jännittävämmältä kuin livealbumilla oleva versio... Ehkä siksi, että se on äänitetty eri keikalta. Näin Värttinän 
Joroisten Musiikkipäivillä viime kesänä ja se Äijö, jonka he soittivat siellä kuulosti uhkaavalta ja pelottavalta."

SANDOR [17.01.2002, 00:13]: "Luulen, että videota ei äänitetty keikalta vaan studiossa. - -"

VIHMAAJA [17.01.2002, 16:44]: "Video nauhoitettiin heidän keikaltaan Nosturissa. Nosturi rules!! - -"

SANDOR [17.01.2002, 19:03]: "Joo, minun täytyy olla eksaktimpi :-Luultavasti se ei ollut live-keikka vaan studiotyyppinen äänitys. Paikka oli Nosturi, kuten pätkässä mainitaan, mutta luulen, että se ei ollut yleisökonsertti. Joka tapauksessa tärkeintä on, että heillä on uusi videopätkä monen vuoden jälkeen ja tämä on tosi hyvä pätkä. Joten odottelen vain, että TV:t pyörittävät sitä tiuhaan (:)"

(Värttinä Forum 2002b.)

Dialogissa erottuu kaksi juonnetta: Äijön live-version vertaaminen studioversioon sekä videon tekotapaa koskevat kommentit. Seuraava viesti, joka on löytyy Ilmatar-albumia koskevasta kansiosta otsikolla "Confusion about Aijo", sivuaa molempia:

TOM FROM CONNECTICUT [21.01.2002, 18:05]: "Näin Värttinän ensimmäisen kerran [viime] lauantai-iltana. Se oli uskomattoman vahva videoesitys ja olen käyttänyt tämän aamun (jolloin minun pitäisi olla töissä) yrittäen jäljittää mitä näin. Olen ladannut videoesityksen, mutta se ei näytä ihan samalta, jonka näin televisiossa (asema oli "Earthlink"); erityisesti ajattelin, että eri nainen näistä neljästä hoiti suurimman osan laulusta ja manauksesta, mutta näyttää siltä, että on vain yksi video bändistä esittämässä tätä laulua. Kysymykseni ovat: onko video saatavilla USA:ssa? Onko useampia kuin tämä yksi video? Onko laulu sekä "Ilmattarella" että "6.12.:1la". Arvostan suuresti mitä tahansa apua. Siitä on PITKÄN aikaa, kun joku musiikkikappale on räjäyttänyt tajuntani tällä lailla."

(Värttinä Forum 2002c.)

Äijöä koskeva keskustelu loppuu tällä erää tähän, mutta jatkuu bokmalin aloittamassa kansiossa heinäkuun lopulla, jolloin yhdysvaltalainen Dyani kommentoi Äijön liveversiota 6.12.:1la: "Aijo [sic] saa minut nauramaan myös, valitettavasti, mutta en usko, että se oli heidän tarkoituksensa kun he äänittivät sen [31.07.2002, 19:00]" (Värttinä Forum 2002b).

Tämän jälkeen Ä̈jöä koskeva keskustelu lakkaa yli kahden kuukauden ajaksi, mutta jatkuu taas marraskuun alussa, kun ontariolainen Iain kommentoi sekä Äijön (video) häneen tekemää vaikutusta että videon tekotapaa:

IAIN [07.11.2002, 05:28]: ’Tämä on ensimmäinen Värttinä-albumi, jonka olen ostanut. En ollut koskaan edes kuullut heistä, kunnes yhtenä yönä surffailin eri kanavilla ja törmäsin Äijö-videoon. Minun täytyy sanoa, että lankesin heihin pahasti. Niinpä [kun] olen nyt 6:12:n ylpeä omistaja, minulla on pari kysymystä siitä.

Ensiksi, video. Minusta näyttää kuin tämä olisi studiossa kuvattu video, mutta ääniraita on albumilta. Tämä tarkoittaa, että he huulisynkkaavat ja että Johanna imitoi 
Riikan laulua. Onko näin? Toinen kysymys: voiko joku kertoa minulle, ketkä tytöt laulavat sooloa missäkin laulussa?"

SCOTT M. GIANELLI [09.11.2002, 20:05]: "Vastaus ensimmäiseen kysymykseesi on kyllä, olen aika varma. En usko, että olisin [itse] tehnyt sitä sillä tavalla, mutta näyttää kuin se olisi tehty niin.

OK, laulusoolot: Kirsi tekee loitsun 'Äijössä' (Johanna tekee sen heidän esityksissään nykyisin), Susan laulaa sooloa 'Meressä' ja 'Liiguassa', Mari laulaa soolon kappaleessa 'Kylä Vuotti Uutta Kuuta'."

(Värttinä Forum 2002b.)

Äijöä ja videon tekotapaa koskeva keskustelu päättyy - ainakin tällä erää - tähän. Kuten edellä on todettu, video on toteutettu Iainin päättelemällä tavalla.

Joulukuun 2001 lopussa suomalainen Tommi avaa Värttinän laulujen sanoitusten

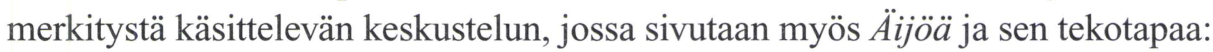

TOMMI [30.12.2001, 18:02]: ’Toinen juttu... kuinka paljon sanoitukset merkitsevät teille? Välitätkö siitä, mistä bändi laulaa. Kuljettaako jokainen sanakirjaa mukanaan yrittäen selvittää, mikä on pointti? (:)

Onko kieli vain instrumentti? Minä olin itse hyvin hämmästynyt [kun minulle selvisi] kuinka kauniilta suomen kieli kuulostaa laulettaessa. Esimerkiksi Mikä miulla mielessä on hyvin ihana. Toisaalta se on rakkauslaulu, joten.. Luulen, että aloitusvokaalit tekevät sen: a-a-o-o-a-a: ainoani armahani omaini oikiain, ainut armas. Tosiaankin: paljon vokaaleja.

Ja sitten taas toisaalta: Pihin neidon sanat ovat ihan päinvastaiset: ikään kuin karkeat ja rumat. Niinpä, aiheena on tyttö, joka ei välitä kylänsä miehistä, ei halua mennä naimisiin tai sänkyyn kenenkään kanssa. Joten se sopii aika hyvin.”

(Värttinä Forum 2002d.)

Aina nopea Sandor vastaa pitkähköllä kommentilla, jonka olennainen sisältö on sen ensimmäisessä lauseessa: "Minusta tässä on kaksi kysymystä: kielen äänteet ja sanoituksen merkitykset [30.12.2001, 20:15]" (Värttinä Forum 2002d). Newyorkilainen Scott M. Gianelli yhtyy Sandorin käsitykseen, mutta korostaa suomen kielen soundin merkitystä Värttinän musiikille:

SCOTT M. GIANELLI [31.12.2001, 08:14]: ’Minä todella pidän siitä, että Värttinän sanoituksissa - ainakin sikäli kuin voin päätellä käännöksistä - on huomattavan paljon syvyyttä, mutta tosiasiassa se on se, miltä sanat kuulostavat, joka sai minut alun perin koukkuun. Heillä on aina ollut upea allitteraatio (konsonanttien toisto), esimerkiksi. Vieraan musiikin (ei vain pohjoismaisen) kuuntelu on lisännyt huomattavasti sitä, miten arvostan ihmisääntä musiikki-instrumenttina."

(Värttinä Forum 2002d.)

Tommi on joulun pyhinä lukenut Kimmo Nevalaisen Korkeelta ja kovvoo -kirjan ja kommentoi nyt teemaa Äijön sanoituksen näkökulmasta: 
TOMMI [31.12.2001, 19:45]: ’Hassua, olen juuri lukenut kirjan Värttinästä. Ja siinä osassa, jossa on nuotit ja sanoitukset, Kirsi kertoo Äijön sanoituksesta. Hän ajatteli, että olisi kiva tehdä sanoitus, jonka sanoissa on paljon ä- ja ö-kirjaimia. En juuri kiinnittänyt siihen huomiota ennen kuin nyt. Nuo vokaalit antavat laululle erilaisen fiiliksen. Ne korostavat vanhan Äijö-äijän pahuutta ja rumuutta. Hmm.. "wedding" on suomeksi häät ja "wedding night" hääyö. Että kerro lisää ihanista sanoista"

(Värttinä Forum 2002d.)

Palstalla on tämän jälkeen pitkään taukoa, mutta elokuussa Elisa palaa vielä aiheeseen:

ELISA [16.08.2002, 18:42]: "Sanoilla on iso merkitys musiikissa (paitsi instrumentaaleissa). En nauttisi sellaisen musiikin kuuntelemisesta, jossa on tyhjänpäiväinen ja tylsä musiikki [sic]. Jos sanat ovat kielellä, jota en ymmärrä, tykkään laulusta, jos sanat "sopivat" siihen. Ja on totta, että eri kirjaimet tuovat lauluun erilaisia tehoja. Minusta "ä” ja "ö” tuntuvat aika hulluilta ja aggressiivisilta. Sitten taas, jos niitä käytetään sellaisten pehmeiden kirjainten kuten "y", "n" ja "m" kanssa [niin nämä] voivat saada sanan kuulostamaan iloisemmalta (helpommalta). Myös terävät kirjaimet kuten "k" ja "j" voivat tuoda mukanaan vihaa niihin [ä- ja ö-kirjaimiin]. Se riippuu myös siitä sanasta, jossa niitä käytetään.”

(Värttinä Forum 2002d.)

Elisan suomen kielen äänteitä koskeva affektiivinen tulkinta on Äijön kannalta kiinnostava erityisesti siksi, että sen mukaan Kirsi Kähkösen foneemivalinta osuu pitkälti yksiin sen tunnetilan kanssa, joka Antto Varilon mukaan toimi biisin lähtökohtana. Se sopii hyvin yhteen myös loitsuun sisältyvän aggression ja vihan kanssa. Kaiken kaikkiaan - huomioon ottaen Vihmaajan ja Sandorin kommentit Äijön pelottavuudesta ja uhkaavuudesta - fanien voi sanoa ymmärtäneen Äijön paljolti biisintekijöiden alkuperäisten intentioiden mukaisesti.

\section{Äijö: 6.12.:n jälkeen}

Vuoden 2001 lopulla Värttinä konsertoi Irlannissa, Venäjällä (Moskova) ja Brasiliassa (São Paulo). Maaliskuussa 2002 on vuorossa Ranska ja Espanja. Värttinä on sama, mutta kuitenkin uusi. Kimmo Nevalaisen (2001: 94) sanoin:

Joustavuus on tyypillistä Värttinälle. Kun live-cd 6.12 äänitettiin joulukuun kuudentena vuonna 2000, kysymyksessä oli sen hetken Värttinä. Kesällä 2001 Värttinä esittää osan samoista lauluista jo eri tavalla, silkasta muuttumisen halusta, mutta kuitenkin niin, että lopulta kuulijat ovat niitä, jotka muutoksesta eniten nauttivat - jos sattuvat asian ymmärtämään.

Osin kysymys on kansanmusiikille luonteenomaisesta muuntelusta, osin kokoonpanon vaihdoksista. Keväällä 2002 viulisti Kari Reiman, basisti Pekka Lehti ja laulaja 
Kirsi Kähkönen jättävät Värttinän. Reimanin tilalle tulee jo vanhassa Värttinässä (1983-89) soittanut ja myöhemminkin Reimania tuurannut Lassi Logren ja Pekka Lehden korvaa Hannu Rantanen, joka hänkin on tilapäisesti esiintynyt Värttinän keikoilla ennen liittymistään. Kirsi Kähkösen tilalle ei oteta uutta laulajaa vaan eturivi jatkaa triona.

Ensimmäinen esiintyminen uudella kokoonpanolla on 2.5.2002 Savoy-teatterissa (yleisön joukossa istuu presidentti Tarja Halonen). Äijö säilyy uuden kokoonpanon ohjelmistossa, loitsun esittäminen lankeaa nyt Johannalle. Heinäkuussa Värttinä esiintyy Rääkkylän Kihauksessa, usean ulkomaisen fanin saapuessa paikalle. Paikalla on myös unkarilainen insinööri Sandor Sebök (Forum-palstan "Sandor"), joka kirjoittaa Äijöstä:

Olin utelias näkemään, kuinka Johanna tekee Äijön manauksen - sen jälkeen, kun Kirsi teki sen niin hyvin. Johanna oli upea ja hän löysi erilaisen [ilmaisu]tavan. Kirsi teki sen jännittävällä ja pelottavalla tavalla ja Johanna teki ikään kuin noituen. Ehkä en käyttänyt oikeita sanoja, mutta toivon, että ymmärrätte. Mari yhtyi häneen manauksen loppuosassa ja yhdessä manaus toimi erittäin hyvin.

(Värttinä Forum 2002e.)

Haastatellessani Kirsi Kähköstä joulukuussa 2002 kysyn häneltä, onko hän kuullut Johannan versiota loitsusta ja jos on, niin haluaako hän kommentoida sitä. Kähkönen (2002) vastaa:

Olen, joo. Tämä on vähän kuin kysyisi mitä Ismo Alanko ajattelee minun esityksestäni. Johanna tekee sen omalla tyylillään, joka on aika erilainen - vähemmän aggressiivinen kuin minun esitykseni. Pääasia, että jokainen saa sen kuulostamaan uskottavalta.

Äijö on mukana myös 28.2.2003 Aleksanterin teatterissa pidetyssä 20-vuotisjuhlakonsertissa. Paikalla olen minäkin. En ole aikaisemmin kuullut Äijöä konsertissa, mutta selvästikin esitys vastaa pitkälti Kihauksessa heinäkuussa 2002 kuultua versiota. Loitsuosuuden aloittaa Johanna, joka sähisee yksin loitsun alkuosan. Suunnilleen "pirun riivattu purija" -säkeen kohdalla mukaan liittyy Mari, myöhemmin myös Susan. Loitsun jälkipuoliskoa - Kirsi Kähkösen kirjoittamaa osuutta - ei nyt manata kokonaisuudessaan vaan laulajat sähisevät tiettyjä avainsäkeitä kuten "pirun riivattu purija" ja "et very miun verellä" yhä uudelleen ja uudelleen, kunnes on aika siirtyä B3-osaan.

Seuraavan sunnuntain Helsingin Sanomissa on Pirkko Kotirinnan arvostelu juhlakonsertista. Äijö saa jälleen erikoismaininnan:

Yhtyeen pitkän iän yksi salaisuus saattaakin piillä siinä, että vaihtelu virkistää, oikeasti. Nyt esimerkiksi Lukkarisen ja Rantasen työskentely oli mainion vivahteikasta kautta linjan, ja nousi huippuunsa $\ddot{A} i j o ̈$-manauksen hurjassa introssa. 
Bändi on hyvässä kunnossa, mutta keskiössä ovat useimmiten laulajat: Kaasisen rinnalla Susan Aho ja Johanna Virtanen. Jokaisessa blondissa on kunnon annos lavasäteilyä, ja kun liikuntakin on vapautunut ja laulu kehittynyt sitten kukkamekkoaikojen, Värttinä on paitsi omaleimainen myös ammattimainen vientiyhtye.

Äijö oli laulunkin kannalta illan hienoimpia hetkiä, Lemmennoston ja Kylä vuotti uutta kuuta -laulun rinnalla. Emoni ennen soi suurena yhdessä Philomena-kuoron kanssa.

(Kotirinta 2003: B3.)

Kesän koti- ja ulkomaankiertueilla Johanna Virtasta tuuraa Philomela-kuoron Karoliina Kantelinen, jonka osalle Äijön loitsu - tai tarkkaan ottaen sen alkuosa - nyt lankeaa. Fanit kommentoivat konsertteja Forum-palstalla ja Karoliinan loitsimaa Äijöä ylistetään useissa arvioissa.

"Caribou" (Varttina Forum 2003a) pitää Antwerpenissa kuulemaansa versiota parhaana koskaan kuulemanaan esityksenä Äijöstä, kun taas "slemi" (Varttina Forum 2003c) sanoo samaa Budapestissa kuulemastaan versiosta. "Laura" ja "imzadi" käyvät sekä Amsterdamin (Melkweg) että Eindhovenin (Folkwoods) konserteissa ja kumpikin pitää erityisesti Äijön esitystä onnistuneena ja mieleenjäävänä (Varttina Forum 2003d). "Sandor" arvioi Antwerpenin esitystä seuraavasti:

Kuten Caribou totesi, Karoliina tuurasi Johannaa tänä iltana. Hän lauloi Tuulen Tunnon ja teki myös loitsun Äijössä. Itse asiassa loitsu ei ole enää varsinainen soolonumero, sillä Mari yhtyi häneen pian (ja pidin oikein kovasti Susanin 'ääniefekteistä' taustalla J) Lopulta kaikki kolme laulajaa tekevät loitsua yhdessä ikään kuin yhteisenä noitumisena.

(Varttina Forum 2003a.)

Kuvauksen perusteella esitys vastaa olennaisilta osiltaan Aleksanterin teatterissa 28.2.2003 kuultua versiota. Kuopiossa Sebök kuulee Värttinän lisäksi livenä myös Ismo Alankoa, Ilmatar-albumin shamaania:

Seuraava tapahtuma oli Ismo Alangon yhtye, Marko Timonen rummuissa. Näin heidät ensimmäisen kerran ja se oli hyvä. Pidin konsertista, kuten paikallinen nuorisokin, hän näyttää olevan hyvin suosittu Suomessa. Puhuin hänen kanssaan joitakin sanoja hotellin baarissa konsertin jälkeen ja hän on ystävällinen kaveri. Kysyin, miksi hän ei tehnyt Aijön [sic] loitsua konsertissa ja hän sanoi, että hän oli valmis, mutta bändi ei kysynyt häntä. J Vahvisti myös, että hän ei koskaan esittänyt sitä livenä, vain kerran studioäänityksessä.

(Varttina Forum 2003b.)

Äijön matka Vihman aikoihin syntyneestä "bassoriffistä” Ilmattarella julkaistuksi versioksi on ollut pitkä ja kappale on muuttunut useaan kertaan matkan aikana. Mutta $\ddot{A} i j o ̈$ on muuttunut paljon myös Ilmattaren jälkeen - ja tulee varmasti muuttumaan jatkossakin sikäli kuin se pysyy Värttinän ohjelmistossa ja Värttinä koossa. Ja miksi ei pysyisi? 


\section{Äijö: perinne- ja populaarimusiikin leikkauspisteessä}

Äijö on nykykansanmusiikkia ja niinpä sen välittymisessä on piirteitä sekä kansanmusiikille että populaarimusiikille ominaisista välittymistavoista. Kansanmusiikin välittymistä määritteleviä piirteitä ovat jatkuvuus, muuntelu ja yhteisön valinta. Populaarimusiikki välittyy musiikkiteollisuuden ja median ehdoin, jolloin prosessissa voidaan erottaa tuotanto, markkinointi, julkinen vastaanotto ja kulutus.

Kansanmusiikille ominainen jatkuvuus eli nykyhetken yhdistäminen menneeseen tulee Ä̈jön kohdalla esiin monin eri tavoin. Mennyttä edustaa suomalais-ugrilainen perinne ja keskiaika. Suomalais-ugrilaiseen perinteeseen Ä̈jön yhdistää ennen muuta biisin nimi, sanoitus (erityisesti loitsun ja parannusmenojen osalta) sekä jouhikon käyttö sovituksessa. Keskiaikaan Äijö liittyy ennen muuta melodiikkansa (modaalinen e-molli) ja sovituksensa (urkupiste, terssittömät soinnut) kautta. Nykyisyyttä $\ddot{A} i$ jössä edustaa eri perinnemusiikkitraditioista ja populaarimusiikista peräisin olevat ainesten yhdisteleminen, fuusio, mikä on ominaista nykykansanmusiikille. Äijössä tällaisia aineksia ovat inkeriläistä "parvessa" laulamista (Asplund 1992) muistuttava laulustemmojen sovitus sekä Välimeren alueen arabivaikutteiseen (balkanilaiseen, espanjalaiseen) musiikkiin viittaavat piirteet (rytmiikka, modaalisuus, urkupiste, he-

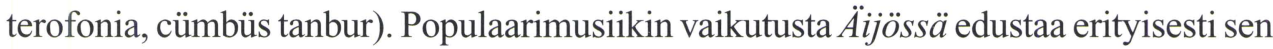
introsta, säkeistöistä, kertosäkeistöistä ja välisoitoista koostuva rakenne. Juuri suomalais-ugrilaisen perinteen luova uudelleentulkinta, menneen yhdistäminen nykyhetkeen, on se, mikä tekee Värttinän musiikista nykykansanmusiikkia.

Muuntelu tarkoittaa sitä, että kappaleesta ei ole yhtä ainoaa "oikeaa" versiota vaan se esitetään eri esityskerroilla jossain määrin eri tavoin. Äijön kohdalla tällainen muuntelu on helpoimmin havaittavissa vertaamalla Ilmatar- ja 6.12.-albumeilla olevia versioita toisiinsa. Ilmeisin ero on se, että Ilmattarella loitsun esittää Ismo Alanko ja 6.12.albumilla Kirsi Kähkönen. Tarkempi vertailu osoittaa kuitenkin, että sovitus on muuttunut myös muilta osin. Fanien kuvaukset kevään ja kesän 2002 live-esiintymisistä osoittavat lisäksi, että Äijön sovitus muuttuu jatkuvasti: esimerkiksi loitsun loppuosan esittävät nyt Johanna Virtanen ja Mari Kaasinen duettona. Että kysymys on Värttinälle ominaisesta asenteesta musiikkiaan kohtaan, käy ilmi paitsi Nevalaisen kirjasta (2001) myös 6.12.-albumin kappaleiden vertailusta samojen kappaleiden alkuperäisiin studioversioihin.

Yhteisön valinta tarkoittaa sitä, että viime kädessä yhteisön jäsenet valitsevat, mikä versio tai mitkä versiot kappaleesta säilyvät. Tämä kriteeri on Äijön kohdalla kaikkein ongelmallisin. Jos pidetään kiinni siitä IFMC:n määrittelystä, jonka mukaan nimenomaan "yhteisön suorittama musiikin uudelleen muokkaus ja uudelleen luominen on se tekijä, joka antaa kansanmusiikille sen kansanomaisen luonteen" (Ling, Lönn \& Ala-Könni 1978: 346; kursivointi lisätty), Äijö ei täytä kansanmusiikin määritelmää. Toisaalta on kuitenkin muistettava, että Värttinä on esittänyt Äijöä live-esiintymisissä 
jo kymmeniä kertoja, ja voidaan olettaa, että kappaleen läpikäymät muutokset ovat ainakin osittain syntyneet vuorovaikutuksessa yleisön kanssa.

Äijö käy Ilmatar-albumin tuotantoprosessin aikana läpi populaarimusiikin tuottamisen päävaiheet "normaalissa" järjestyksessä: biisinteko, sovitus, äänitys, miksaus ja julkaiseminen. Myös itse äänitysprosessi etenee "normaalissa" järjestyksessä: ensin pohjat, sitten lauluäänet ja lopuksi ekstrat. Populaarimusiikin tuottamistapaan viittaa myös tuottaja Hughes de Coursonin vahva rooli soundimaailman muokkaajana ja albumille mukaan otettavien kappaleiden valitsijana. Värttinän kohdalla tämä rooli ei kuitenkaan perustu tuottajan institutionaaliseen asemaan vaan yhteiseen sopimukseen. Myös sekä soitin- että lauluosuuksien äänittäminen studiolive-pohjalta poikkeaa vallitsevasta populaarimusiikin äänityskäytännöstä.

Ilmatar-albumin julkaisemisen yhteydessä Äijö törmää levyteollisuutta sääteleviin armottomiin liiketaloudellisiin lakeihin: levy-yhtiö BMG lopettaa Wicklow-merkin kannattamattomana ennen kuin Ilmatar ehditään julkaista USA:ssa. Värttinä hankkii lisenssin itselleen ja Ilmatar julkaistaan USA:ssa NorthSide-levymerkillä. 6.12.-albumin julkaisuoikeudet Värttinä pitää alun alkaenkin itsellään. NorthSide julkaisee 6.12.-albumin nimellä Live in Helsinki. Albumeista tiedotetaan medialle ja jälleenmyyjille normaalin uutuuksia koskevan käytännön mukaisesti. NorthSidella on omat sivunsa sekä Ilmatar- että Live in Helsinki -albumille.

Värttinän uuden albumin ilmestyminen on uutinen musiikkilehdistölle ja päivälehtien kulttuuripalsoille. Ilmatar- ja 6.12.-albumien julkaisemiseen liittyen Värttinästä ilmestyy reportaaseja sekä kotimaisissa (Friiti, Helsingin Sanomat, Rytmi) että kansainvälisissä (Folk Roots, Global Rhythm, Sing Out!) lehdissä. Myös Finnairin Blue Wings (Europe) -lehti julkaisee Värttinä-artikkelin. Arvosteluja ilmestyy lukuisissa sanoma-, aikakaus- ja nettilehdissä. Markkinointi ja arvostelut ovat dialogissa keskenään siten, että levy-yhtiö (NorthSide) ja levyjä välittävät liikkeet (mm. Amazon ja Barnes \& Noble) käyttävät markkinoinnissaan musiikkilehdissä julkaistuja levyarvosteluja.

Äijön "kulutus" noudattelee pääosin populaarimusiikin tavanomaisia kulutustapoja. Äijöä kuunnellaan levyltä (Ilmatar, 6.12.), katsellaan ja kuunnellaan videolta (6.12., Värttinän nettisivut), minkä lisäksi käydään Värttinän konserteissa. Aineistossa toistuu myös tilanne, jossa Värttinää aiemmin tuntematon ulkomaalainen näkee ja kuulee yllättäen $\ddot{A i j o ̈-v i d e o n ~(t a i ~ k o n s e r t t i t a l t i o i n n i n) ~ t e l e v i s i o s s a ~ j a ~ e s i t y s ~ t e k e e ~ h a ̈ n e e n ~ n i i n ~ s u u-~}$ ren vaikutuksen, että hän hankkii 6.12.:n käsiinsä. Yllättävä törmääminen ja sitä seuraava "lankeaminen" voi tapahtua myös festivaaleilla tai Internetissä. Innokkaimmat fanit saapuvat Värttinän konsertteihin satojen tai jopa tuhansien kilometrien päästä. Äijön "kulutus" toteutuu myös Värttinän nettisivujen Forum-palstalla, jossa fanit vaihtavat mielipiteitään Ä̈jöstä ja muista Värttinän kappaleista. Palstan ylläpitäjän järjestämässä Värttinä TOP 5 -äänestyksessä Äijö on suosituin kappale (Värttinä Forum 2002f).

Kaiken kaikkiaan Äijön tarkasteleminen samanaikaisesti sekä perinne- että populaarimusiikin näkökulmasta näyttää edellisen perusteella mielekkäältä. IFMC:n São 
Paulon kongressissa vuonna 1954 hyväksymä kansanmusiikin määritelmä sopii jatkuvuus- ja muunteluaspektien osalta Ä̈jöön hyvin, yhteisön valinnan osalta rajoitetummin. Äijöä on kuitenkin mielekästä tarkastella myös populaarimusiikin tuotannon, markkinoinnin ja kulutuksen näkökulmasta. Huomattavaa on, että myös tämä prosessi tukee perinteen jatkuvuutta ja muuntelua antamalla eri vaiheissaan Ä̈jölle paitsi sitä suomalais-ugrilaiseen perinteeseen yhdistäviä myös tätä perinnettä uudelleentulkitsevia merkityksiä.

Selkeimmin perinne- ja populaarimusiikin välittymisen erot tulevat esiin valintaaspektin kohdalla. Populaarimusiikissa ja yleensäkin musiikkiteollisuuden ja median ehdoin toimivassa musiikissa valinta on siirtynyt yhteisön jäseniltä musiikkiteollisuuden ja median eri instituutioita edustaville portinvartijoille (tuottaja, manageri, levyyhtiön markkinointiosasto, toimittajat, vähittäiskauppiaat jne.). Yhteisön valinnan tilalla on portinvartijoiden tekemä esivalinta.

Tältäkin osin Äijön tapaus kuitenkin heijastelee muutosta. Tällä hetkellä Värttinä omistaa Ilmatar- ja 6.12.-albumien lisenssit ja neuvottelee albumien julkaisemisesta eri maissa paikallisesti eri levymerkkien kanssa. Siten yhtye ei enää ole täysin sidottu levy-yhtiöiden suhdannevaihteluihin kuten se oli Nonesuch- ja Wicklow-sopimusten kohdalla. Tämän lisäksi Värttinä välittää nettisivujensa kautta tietoa ja materiaalia suoraan faneille ohi portinvartijasysteemin. $̈$ Äjö-video on nähtävissä ja ladattavissa Värttinän kotisivuilta. Fanit eivät tyydykään portinvartijoiden heille "suodattamaan" informaatioon vaan hankkivat aktiivisesti tietoa Värttinän sivuilta ja osallistuvat sivujen Forum-palstalla käytävään keskusteluun. Edellä kuvatun kaltaiset muutokset eivät tietenkään koske vain Värttinää ja Äijöä tai yleensä nykykansanmusiikkia vaan yhä enenevässä määrin myös varsinaista populaarimusiikkia.

\section{Viitteet}

1 Tutkimus on osa akatemiatutkijan virkaani liittyvää Suomen Akatemian tutkimushanketta "Historiallisuus, omaelämäkerrallisuus ja nostalgia aikamme suomalaisessa populaarimusiikissa".

2 Ilmaisu "ugrilainen alkuvoima" on peräisin $\mathrm{Hel}$ singin Sanomissa 2.5.2000 julkaistusta, Pirkko Kotirinnan kirjoittamasta Ilmatar-albumin arvostelusta (Kotirinta 2000b), jota siteeraan tuonnempana yksityiskohtaisemmin.

\section{Lähteet}

\section{TUTKIMUSKIRJALLISUUS}

Asplund, Anneli (1992) Kansanlauluja Inkerinmaalta. Toimittanut Anneli Asplund. Helsinki: Suomalaisen Kirjallisuuden Seura. 
Elderen, Louis P. van (1993) "Between Tradition and Modernity - In Search of the Meaning of Finnish Folk Music". On the Borderlines of semiosis: Proceedings from the ISI Conferences in Imatra, 1991 and 1992 (Acta Semiotica Fennica II). Toim. Eero Tarasti. Imatra: International Semiotics Institute. Ss. 361-375.

Elderen, Louis P. van (1994) "Finnish popular music, culture and national identity. Some questions by an outsider.' Etnomusikologian vuosikirja 6. Toim. Erkki Pekkilä. Helsinki: Suomen etnomusikologinen seura. Ss. 50-65.

Elderen, Louis P. van (1996) "Värttinä, Culture and Fun - But Not for Kids? "Youth in Changing Societies. Toim. Vesa Puuronen. Bulletins of the Faculty of Education 58. Joensuu: University of Joensuu. Ss. 100-112.

Frith, Simon (1987) Sound effects - Youth, leisure, and the politics of rock'n'roll. London: Constable.

Kaasinen, Sari (1994) "Ommoo hommoo korkeelta ja kovvoo" - Värttinä Oi Daista Aitaraan. Sibelius-Akatemian kansanmusiikin koulutusohjelman muusikon suuntautumisvaihtoehdon kirjallinen työ. Moniste.

Karpeles, Maud (1973) An Introduction to English Folk Song. London: Oxford University Press.

Kurkela, Vesa (1995) "Globaalit soinnit". Musiikin suunta 17(1995)/1, ss. 4-10.

Kurkela, Vesa (2001) "Bulgarian tshalgavideot, poliittisuus ja orientalismi". Etnomusikologian vuosikirja 13 (2001). Toim. Jarkko Niemi. Helsinki: Suomen etnomusikologinen seura.

Kärjä, Antti-Ville (1997) "Musiikkivideo intertekstinä. Tapausanalyysi Havana Black -yhtyeen videosta East Is Red". Etnomusikologian vuosikirja 9 (1997). Toim. Jukka Louhivuori. Helsinki: Suomen etnomusikologinen seura. Ss. 183-201.

Lassila, Juha (1987) Kultalevyn alkemia - Rockteollisuus musiikin suodattajana. Nykykulttuurin tutkimusyksikön julkaisuja 6. Jyväskylä: Jyväskylän yliopisto.

Lehtiranta, Erkki (1993) "Musiikkijournalismin suuntaviivoja - Laaja kenttä ilman tarkkoja rajoja". Musiikkijournalismi-musiikin ja median kohtaamisia. Toim. Erkki Lehtiranta \& Kristiina Saalonen. Sibelius-Akatemia: Helsinki (Sibelius-Akatemian koulutusjulkaisuja 9). Ss. 10-25.

Ling, Jan \& Lönn, Anders \& Ala-Könni, Erkki (1978) "Kansanmusiikki ”. Otavan Iso Musiikkitietosanakirja, osa 3. Keuruu: Otava. Ss. 346-347.

Lähteenmaa, Jaana (1989; toim.) Rockin seksuaalisuus. Helsinki: Gaudeamus.

Muikku, Jari (1988) Vinyylin viemää-Ä̈̈nilevyn tuottamisen karu todellisuus. Työväenmusiikki-instituutin julkaisuja 7. Helsinki: Työväenmusiikki-instituutti.

Nevalainen, Kimmo (2001) Värttinä: Korkeelta ja kovvoo - Historia, musiikki ja nuotit. Helsinki: Like.

Oesch, Pekka (1989) Musiikkiarvostelun tuolla puolen: Neljä näkökulmaa rockkritiikkiin. Työväenmusiikki-instituutin julkaisuja 8. Helsinki: Työväenmusiikki-instituutti.

Offermann, Hertaldis (1998) "Värttinä ja uusi kansanmusiikki". Musiikin suunta 20 (1998/ 2), ss. 32-38.

Pegg, Carole (2003) "Folk Music". The New Grove Dictionary of Music Online. Ed. L. Macy. http://www.grovemusic.com (tarkistettu 20.9.2003).

Pekkilä, Erkki (1998) "Nykykansanmusiikki tutkimuskohteena”. Musiikin suunta 20 (1998/ 2), ss. 4-8.

Pensas, Susanna (1995) "Toimittaja Värttinän taustalla - Erä musiikin ja journalismin pelistä". Musiikin suunta 17 (1995)/1, ss. 36-42. 


\section{TUTKIMUSAINEISTO}

BMG (2001b) BMG-uutuuksia 35/2001. http://www.click2music.fi/finland/viikkarit/vk35/ vk35.htm (tarkistettu 19.9.2002).

BMG (2001a) BMG-uutuuksia 34/2001. http://www.click2music.fi/finland/viikkarit/vk34/ vk34.htm (tarkistettu 19.9.2002).

Click2Music (2001) "Värttinä". Artistibiografia. http://www.click2music.fi/biografi. asp?art=209 (tarkistettu 22.11.2001).

Cronshaw, Andrew (2000) "Värttinä: Ilmatar". Folk Roots 22(2000)/4, s. 54.

Cronshaw, Andrew (2001) "Beating Varts". Folk Roots 22(2001)/11, ss. 41-43.

Hämekoski, Kari (2002) "Värttinä: 6.12.”. Rytmi 1/2002. http://www.rytmi.com/rytmi102/ 102kiekot.html (tarkistettu 19.9.2002).

Hämekoski, Kari (2001) "Värttinä: Ilmatar". Rytmi 3/2000. http://www.rytmi.com/rytmi300/3kiekkorinki.html (tarkistettu 22.11.2001).

Jääskä, Marjo (2000) "Värttinä: Ilmatar". Suomen kansanmusiikkiliitto. http://www. suomenkansanmusiikkiliitto.fi/pages/uutuusarviot19.html (tarkistettu 19.9.2002).

Kotirinta, Pirkko (2000b) "Akustista ilmaa siipien alle - Ilmatar esittelee kypsyneen Värttinän”. Helsingin Sanomat 2.5.2000. http://www.helsinginsanomat.fi/arkisto/juttu.asp?id= 20000502KU3 (tarkistettu 13.12.2002).

Kotirinta, Pirkko (2000a) "Kansallispukuryhmästä maailmanmusiikiksi". Helsingin Sanomat 2.5.2000. http://www.helsinginsanomat.fi/arkisto/juttu.asp?id=20000502KU1 (tarkistettu 13.12.2002).

Kotirinta, Pirkko (2003) ”Budapestista Värttinän juhliin”. Helsingin Sanomat 2.3.2003, s. B3. Lehtoranta, Hannu (2000) "Värttinä: Ilmatar". Friiti 3/2000, s. 50.

Lien, James (2001) "Varttina: Ilmatar". CMJ New Music Report Issue 700. wysiwyg://55/ http://www.cmj.com/articles/display_article.php?id=30021 (tarkistettu 16.1.2003).

Mattila, Ilkka (2000) "Rönsyilyä varmalta pohjalta - Värttinän hifi-kausi vaihtui spontaanimpaan soittoon". Helsingin Sanomat 2.5.2000. http://www.helsinginsanomat.fi/arkisto/juttu.asp?id=20000502KU2 (tarkistettu 13.12.2002).

Moll, Christian \& Moll, Michael (2000) "Värttinä: Ilmartar" [sic]. FolkWorld, 14(2000)/6. http://www.folkworld.de/14/e/cds3.html (tarkistettu 14.12.2002).

Mäkinen, Esa (2000) "Värttinän uusin on Ilmatar". Friiti 1/2000, ss. 6-7.

Nevalainen, Kimmo (2000) "Värttinä teki taidelevyn". Verkko-Karjalainen 30.4.2000. http:/ www.karjalainen.fi/cgi-bin/vk?/News...\&Model=ajuttusivu.html\&Story=00742661.txt (tarkistettu 12.1.2003).

Nickson, Chris (2001) "Cool Harmonies / World Beat Heat". Sing Out! 45(2001)2.

Nickson, Chris (2002a) "Varttina Finish Finnish Myth Cycle With Ilmitar [sic] - Band's eight album nearly lost to contractual limbo." VH1.COM, 13.2.2001. wysiwyg://107/ http://www.vh1online.com/artists/news/1439320/02122001/varttina.jhtml (tarkistettu 16.1.2003).

Nickson, Chris (2002c) "Värttinä: Ilmatar". Amazon.com. http://www.amazon.com/exec/ obidos/tg/stores/detail/-/music/B0000584U6/reviews/ref=cm_rev_all_1/103-11098783545464 (tarkistettu 24.9.2002).

Nickson, Chris (2002b) "Värttinä: Ilmatar". Barnes \& Noble.com. http://music.barnes andnoble.com/search/product.asp?userid $=$ OMXXBBQYVJ\&wrk=5017215 (tarkistettu 24.9.2002).

Nickson, Chris (2003) "Värttinä - Ilmatar". Mondomix. wysiwyg://42/http://www.mondo mix.org/mix_us/reviews_us/reviews_artists/ilmatar.htm (tarkistettu 21.1.2003). 
NorthSide (2002a) "Ilmatar by Värttinä". http://www.noside.com/Catalog/CatalogAlbum _01.asp?Album_ID=128 (tarkistettu 19.9.2002).

NorthSide (2002b) "Live in Helsinki by Värttinä". http://www.noside.com/Catalog/Catalog Album_01.asp?Album_ID=164 (tarkistettu 19.9.2002).

NorthSide (2002c) "NorthSide News". http://www.noside.com/news.html (tarkistettu 20.9.2003).

Rekinen, Jyri-Jussi (2000a) "Värttinä manaa Ilmattaren loitsuja." Rytmi 3/2000. http:// www.rytmi.com/3varttinamanaa.html (tarkistettu 22.11.2001).

Rekinen, Jyri-Jussi (2000b) "Hughes de Courson: Ainutlaatuisia ääniä - ainutlaatuinen bändi." Rytmi 3/2000. http://www.rytmi.com/3varttinadecourson.html (tarkistettu 22.11. 2001).

Rekinen, Jyri-Jussi (2000c) "Philip Page - Agenttiverkoston päämies". Rytmi 3/2000. http:/ /www.rytmi.com/3varttinapage.html (tarkistettu 22.11.2001).

Roden, Christina (2002) "Värttinä: Ilmatar". RootsWorld. http://www.rootsworld.com/reviews/ilmatar.shtml (tarkoitettu 19.9.2002).

Steckelberg, Nico (2002) "Värttinä: '6.12.' (Live)". Holtedripolter Musik Magazin. http:// www.holterdipolter.net/p_r_varttina.html (tarkistettu 13.12.2002).

Stenger, Wif (2002) "Ancient Roots - Bright New Shoots". Blue Wings (Europe) FebruaryMarch 2002, ss. 24-25.

Tarte, Bob (2002a) "Värttinä, Wimme - Live in Helsinki, Gierran, Cugu". Miami New Times, 2.5.2002. http://www.miaminewtimes.com/issues/2002-05-02/smallworld.html/ print.html (tarkistettu 24.9.2002).

Tarte, Bob (2002b) "Forces of Nature". The Beat Magazine (Technobeat archives), 21(2002)/ 3. http://www.technobeat.com/COLUMNS/Forces.html (tarkistettu 13.12.2002).

Värttinä (2002) "Värttinä - 'Äijö'”. http://www.varttina.com/videos/ (tarkistettu 13.12. 2002).

Varttina Forum (2002a) "Comments about 6.12.". http://forum.varttina.net/cgi-bin/ ultimatebb.cgi?ubb=get_topic $\& \mathrm{f}=18 \& \mathrm{t}=000002$ (tarkistettu 5.12.2002).

Varttina Forum (2002b) "Confusion about 'Aijo"'. http://forum.varttina.net/cgi-bin/ ultimatebb.cgi? $\mathrm{ubb}=$ get_topic $\& \mathrm{f}=17 \& \mathrm{t}=000003$ (tarkistettu 5.12.2002).

Varttina Forum (2002c) "Lyrics: matters or not?" http://forum.varttina.net/cgi-bin/ ultimatebb.cgi?ubb=get_topic $\& \mathrm{f}=4 \& \mathrm{t}=000002$ (tarkistettu 5.12.2002).

Varttina Forum (2002d) "Jul 4, 2002 - Rääkkylän Kihaus". http://forum.varttina.net/cgi-bin/ ultimatebb.cgi?ubb=get_topic $\& \mathrm{f}=3 \& \mathrm{t}=000009$ (tarkistettu 13.12.2002).

Varttina Forum (2002e) "Your Five Favourite Värttinä Songs?” http://forum.varttina.net/cgibin/ultimatebb.cgi?ubb=get_topic $\& \mathrm{f}=9 \& \mathrm{t}=000001$ (tarkistettu 5.12.2002).

Varttina Forum (2003a) "Antwerp concert - short review". http://forum.varttina.net/cgi-bin/ ultimatebb.cgi?ubb=get_topic $\& \mathrm{f}=3 \& \mathrm{t}=000020$ (tarkistettu 18.9.2003).

Varttina Forum (2003b) "July 01, 2003 - Kuopio". http://forum.varttina.net/cgi-bin/ ultimatebb.cgi?ubb=get_topic \&f=3\&t=000028 (tarkistettu 18.9.2003).

Varttina Forum (2003c) "4. august, 2003, Budapest, Sziget-fesztival". http://forum. varttina.net/cgi-bin/ultimatebb.cgi?ubb=get_topic $\& \mathrm{f}=3 \& \mathrm{t}=000025$ (tarkistettu 18.9. 2003).

Varttina Forum (2003d) "Melkweg \& Folkwoods". http://forum.varttina.net/cgi-bin/ ultimatebb.cgi?ubb=get_topic \&f=3\&t=000027 (tarkistettu 18.9.2003). 


\section{VÄRTTINÄ, ÄIJÖ JA PERINTEEN UUDELLEENTULKINTA}

\section{HAASTATTELUT}

Kähkönen, Kirsi (2002) Puhelinhaastattelu 18.12.2002.

Hemmi, Risto (2002) Puhelinhaastattelu 18.12.2002.

Varilo, Antto (2002) Sähköpostihaastattelu. Kysymyslista lähetetty 18.12.2002, vastaus saatu 22.12.2002.

\section{ÄÄNITTEET}

Värttinä (2001) Ilmatar, CD-levy BMG (RCA) 74321881792.

Värttinä (2001) 6.12. , CD-levy BMG 743218818038. 